NBER WORKING PAPER SERIES

\title{
EVALUATING POST-SECONDARY AID: ENROLLMENT, PERSISTENCE, AND PROJECTED COMPLETION EFFECTS
}

\author{
Joshua Angrist \\ David Autor \\ Sally Hudson \\ Amanda Pallais \\ Working Paper 23015 \\ http://www.nber.org/papers/w23015 \\ NATIONAL BUREAU OF ECONOMIC RESEARCH \\ 1050 Massachusetts Avenue \\ Cambridge, MA 02138 \\ December 2016
}

We are grateful to the staff of the Susan Thompson Buffett Foundation for their expert assistance in implementing this evaluation. We also thank the Provost's Office at the University of Nebraska, the Nebraska State College System, and Nebraska's community colleges for supporting this effort and sharing their data. Nick Gebbia, Tyler Hoppenfeld, Sookyo Jeong, and Olivia Kim provided outstanding research assistance with this paper. Sydnee Caldwell, Enrico Cantoni, Annice Correia, Eryn Heying, Brendan Malone, and Karen Scott were instrumental in the project's early stages. We thank Raj Chetty, Amy Finkelstein, Nathan Hendren, Lisa Kahn, Lawrence Katz, Danielle Li and seminar participants at the Advances in Field Experiments Conference, ASSA Meetings, Econometric Society Meeting, NBER Summer Institute, Robert LaLonde Festschrift Conference, Columbia, Harvard, IIES MIT, Stanford, University of Virginia, and Yale for their many helpful comments and suggestions. We acknowledge financial support from the Susan Thompson Buffett Foundation, the MIT SEII seed fund, and the National Science Foundation Graduate Research Fellowship No. 1122374 (Hudson) and CAREER Grant No. 1454476 (Pallais). The views expressed here are those of the authors alone and do not necessarily reflect those of the institutions or funders involved with this work. This RCT was registered with the American Economic Association under trial number AEARCTR-0000125. The views expressed here are those of the authors alone and do not necessarily reflect those of the institutions or funders involved with this work.

NBER working papers are circulated for discussion and comment purposes. They have not been peer-reviewed or been subject to the review by the NBER Board of Directors that accompanies official NBER publications.

(C) 2016 by Joshua Angrist, David Autor, Sally Hudson, and Amanda Pallais. All rights reserved. Short sections of text, not to exceed two paragraphs, may be quoted without explicit permission provided that full credit, including (C) notice, is given to the source. 
Evaluating Post-Secondary Aid: Enrollment, Persistence, and Projected Completion Effects

Joshua Angrist, David Autor, Sally Hudson, and Amanda Pallais

NBER Working Paper No. 23015

December 2016

JEL No. I21,I22,I23,I24,I28,J24

\begin{abstract}
$\underline{\text { ABSTRACT }}$
This paper reports updated findings from a randomized evaluation of a generous, privatelyfunded scholarship program for Nebraska public college students. Scholarship offers boosted college enrollment and persistence. Four years after award receipt, randomly-selected scholarship winners were 13 percentage points more likely to be enrolled in college. Enrollment effects were larger for groups with historically low college attendance, including nonwhite students, firstgeneration college-goers, and students with low high school GPAs. Scholarships shifted many students from two- to four-year colleges, reducing associate's degree completion in the process. Despite their substantial gains in four-year college enrollment, award winners from the first study cohort were slightly less likely to graduate on time than control applicants, suggesting that scholarships delay degree completion for some students. Projected graduation rates using the last cohort of pre-experimental scholarship applicants indicate that scholarships are likely to increase bachelor's degree completion within five years.
\end{abstract}

Joshua Angrist

Department of Economics, E52-436

MIT

77 Massachusetts Avenue

Cambridge, MA 02139

and NBER

angrist@mit.edu

David Autor

Department of Economics, E52-438

MIT

77 Massachusetts Avenue

Cambridge, MA 02139

and NBER

dautor@mit.edu
Sally Hudson

Garrett Hall L032

235 McCormick Road

Charlottesville, VA 22904-4893

USA

sally.hudson@virginia.edu

Amanda Pallais

Department of Economics

Harvard University

Littauer Center

Cambridge, MA 02138

and NBER

apallais@fas.harvard.edu

A randomized controlled trials registry entry is available at

https://www.socialscienceregistry.org/trials/125/history/4037 


\section{Introduction}

The Susan Thompson Buffett Foundation (STBF) offers scholarships to Nebraska high school graduates who attend the state's public colleges and universities. STBF is one of the largest private grant providers in the country, funding more than 4,000 students with $\$ 36$ million in aid every year. Its awards are generous: the largest STBF awards provide more than $\$ 70,000$ toward five years of study at Nebraska public institutions. The Foundation selects award winners on the basis of financial need, high school GPA, and a review of personal statements and reference letters. STBF aid recipients, known as Buffett Scholars, can use their awards to cover costs at any University of Nebraska (NU) or State College campus, along with any of the state's six community colleges. Buffett Scholars who attend one of the three NU campuses also participate in Learning Communities (LCs), a Foundation-supported academic services intervention similar to other Learning Communities programs around the country. ${ }^{1}$

To measure the impacts of grant aid and Learning Community services, we implemented a large randomized evaluation of the STBF program. Between 2012 and 2016, STBF awarded more than 3,700 of its scholarships via random assignment. Our earlier working paper (Angrist et al. 2014) reports award effects on college enrollment and sophomore persistence for the first two experimental cohorts of students, who started college in the fall of 2012 and 2013. The results reported here add two new cohorts (2014 and 2015) and follow the 2012 applicants through their fourth post-award academic year. The latest data allow us to measure initial college completion effects and investigate enrollment and persistence with much greater precision.

The new results reinforce our earlier findings that STBF scholarships alter students' enrollment behavior. Awards offered to high school seniors who planned to attend community colleges boosted initial enrollment by five percentage points and dramatically increased transfers to bachelor's degreegranting institutions over time. Four years after award receipt, community college scholarship winners from the first cohort were 50 percent more likely to be enrolled at post-secondary institutions than students not offered Buffett aid. Awards offered to students who aspired to attend four-year colleges had smaller effects on initial enrollment since 96 percent of control students in this group

\footnotetext{
${ }^{1}$ See Weiss et al. (2015) for a review of research on LC impacts.
} 
enrolled in college. Still scholarships boosted their initial enrollment by three points, a gain that increased to 13 points by the end of senior year.

The large and heterogeneous STBF applicant pool reveals important variation in aid effects across subgroups. Retention increased most among groups with high expected dropout rates in the absence of treatment: nonwhite applicants, first-generation college-goers, and students with low high school GPAs. On the whole, STBF scholarships substantially reduced persistence gaps across demographic groups.

To distinguish the effects of STBF's financial aid from those of LC services, we randomly offered some applicants an aid-only treatment that excluded access to LCs. This treatment, known to applicants as the College Opportunity Scholarship (COS), offered financial support to NU applicants in the same amounts and under the same conditions as full STBF awards but without offering seats in the Foundation-sponsored LC programs at NU campuses. Aid-only awards generated average enrollment gains on par with the combination aid and LC treatment. However, the combination treatment — aid plus Learning Community support — appears more effective than aid alone for students with lower high school GPAs.

Although STBF awards generated clear and impressive enrollment gains, the picture for degree completion remains unclear. Awards shifted community-college-bound students to four-year schools without increasing associate's degrees in the process. Roughly half of all control applicants in the 2012 community-college-bound group earned associate's degrees within four years of high school graduation. The associate's degree completion rate was 12 points lower among scholarship recipients in this group, an imprecisely estimated effect. Scholarship winners who targeted four-year schools were also less likely to complete bachelor's degrees within four years than were control students. Though on-time graduation rates were low — less than 30 percent — for both groups, scholarship support further delayed completion. A likely explanation for this pattern is that STBF scholarships fund up to five years of study, thereby decreasing financial pressure for on-time completion. Despite the initial delays, we project that scholarships will ultimately increase bachelor's degree completion using data from an earlier cohort of non-randomized scholarship applicants.

The next section briefly reviews STBF program parameters and the design of our ongoing experiment. Section 3 discusses the scholarships' effects on students' financial aid packages. Section 4 reports reduced-form estimates of award effects on enrollment for students targeting two- and four- 
year colleges, including effects in key demographic subgroups. Section 5 presents provisional results from the aid-only treatment arm, and Section 6 discusses preliminary effects on degree completion. Section 7 concludes by summarizing the findings to date and briefly discussing our work in progress.

\section{Background}

\subsection{The STBF Scholarship Program}

The Susan Thompson Buffett Foundation is the largest private grant provider in Nebraska and among the largest in the country, supporting more than 4,000 students with $\$ 36$ million each year. STBF scholarships are available to Nebraska-resident high school seniors and graduates of in-state high schools who have not yet been to college. The program is widely known in Nebraska and well-publicized to potential applicants. More than half of all Pell-eligible Nebraska seniors who file for federal aid also apply for Buffett grants. ${ }^{2}$

STBF award criteria combine the academic standards of many state aid programs with the means testing of federal student aid. Eligible applicants must attain a 2.5 high school GPA and document financial need using the Free Application for Federal Student Aid (FAFSA). STBF gauges financial need using FAFSA's Expected Family Contribution (EFC) metric, which depends chiefly on family size and income. ${ }^{3}$ The maximum Buffett-eligible EFC- $\$ 15,000$ in 2012 and $\$ 10,000$ thereafter $^{4}$ - exceeds the federal Pell Grant cutoff, which ranged from $\$ 5,000$ to $\$ 5,300$ between 2012 and 2015. Buffett awards are therefore available to many students who do not qualify for federal grants or other state-funded programs tied to Pell receipt.

Within the pool of eligible applicants, STBF's merit assessment is more fine-grained than most state programs, incorporating transcripts, essays, and reference letters. Students submit their application materials online between November 1 and February 1, with FAFSA records due by March 15. Reviewers then evaluate eligible applicants using a rubric that emphasizes academic achievement, financial need, and leadership skills. STBF notifies award winners in mid-April, and more than 94 percent of scholarship winners accept their awards.

\footnotetext{
${ }^{2}$ Authors' calculations from data obtained by request from the Federal Student Aid office.

${ }^{3}$ Dynarski and Scott-Clayton (2007) provide further detail on the FAFSA and EFC formula.

${ }^{4}$ Less than eight percent of the 2012 randomized sample had EFCs greater than $\$ 10,000$, so the 2013 change in eligibility requirements had little impact on the EFC distribution across cohorts.
} 
Buffett awards can be used to cover expenses at any public undergraduate institution in Nebraska, including two- and four-year colleges. Award amounts vary by campus but are calibrated to match the cost of tuition and fees for a full-time student plus a $\$ 500$ allotment for books. In 2015 , for example, awards provided up to $\$ 8,700$ per academic year for full-time students at the University of Nebraska-Lincoln, where full-time resident tuition and fees were $\$ 8,382$ (University of Nebraska-Lincoln 2015). STBF provides an additional semester's worth of funding for summer enrollment so that the maximum 2015 award was $\$ 13,050$ at the University of Nebraska and $\$ 5,700$ at community colleges. Though tuition levels determine the value of Buffett grants, the funds can be used to cover any of the federally-defined components of cost-of-attendance (COA), including room, board, books, and supplies. This flexibility boosts STBF's scholarship value relative to aid programs that cover only tuition and fees. Because most Buffett Scholars also qualify for state and federal tuition grants, STBF aid often covers the remaining balance of COA, eliminating the need for loans and out-of-pocket contributions to college costs. Buffett awards are renewable for up to five years provided students meet minimal academic requirements, though no more than three years of funding can be paid toward community college expenses. Students enrolled for fewer than nine credits per semester or with cumulative GPAs below 2.0 risk losing their scholarships.

Buffett Scholars who attend one of NU's three campuses - Lincoln (UNL), Omaha (UNO), or Kearney (UNK) - are required to participate in STBF-funded Learning Community (LC) programs during their first and second years. ${ }^{5}$ These programs are designed to promote academic success and social engagement. While the LC programs differ somewhat by campus, they all include special classes for Buffett Scholars, a collection of academic and social activities, peer mentoring, and academic advising services from LC faculty and staff. Most participants in the LC programs at UNK and UNL live in dedicated dorm space. Buffett Scholars who fail to participate in LC activities may also lose their scholarships.

\subsection{Research Design and Sample Construction}

From 2012 to 2015, STBF awarded the majority of its scholarships via stratified random assignment. The Foundation divided students into strata by their "target college," the institution

\footnotetext{
${ }^{5}$ The STBF-sponsored Thompson Learning Community program is named in honor of William H. Thompson, the father of Susan T. Buffett, who served as Professor of Psychology and Dean of the College of Arts and Sciences at Omaha University, now known as the University of Nebraska Omaha (UNO).
} 
where applicants indicated they would enroll if offered awards. Award winners were not required to follow their stated plans, but 87 percent of aid recipients did indeed attend their target schools. Within each target college stratum, STBF further divided students into three groups by application score. Students in the highest-scoring group received guaranteed awards, the middle group was subject to random assignment, and the lowest-scoring students were disqualified. Score thresholds and award rates for the randomized group were determined by STBF preferences for award counts at each campus. ${ }^{6}$ Appendix Table A1 reports award counts for each target college and cohort. The Foundation offered roughly 300 guaranteed awards each year, with a relatively stable distribution of awards across campuses from year to year. Due to increased Foundation outreach, the number of eligible applicants grew over time and with it the randomized sample, from 999 in the first experimental cohort to 1,878 by the fourth study year. ${ }^{7}$ In total, 6,183 applicants were subject to random assignment between 2012 and $2015 .^{8}$

To distinguish the effects of STBF's financial aid from those of LC services, we randomly offered some applicants the aid-only College Opportunity Scholarship (COS). These aid-only awards match traditional STBF scholarships in financial support but omit access to Buffett LCs. COS awards were made only to applicants in the NU strata of the randomized sample. Because the COS treatment arm did not commence until the second year of our study and is smaller than the other experimental groups, our COS impact estimates are less precise than results for full STBF awards. We exclude COS recipients from our analysis except in Section 5 where we explicitly analyze the COS treatment.

The earlier experimental cohorts naturally provide a longer follow-up horizon than more recent cohorts. We report initial enrollment effects for the 2012-2015 cohorts; year two results for the 2012-2014 cohorts; year three impacts for the 2012 and 2013 cohorts; and year four results for the 2012 cohort. Effects differ little from one cohort to another and cohort pooling increases precision. Estimated pooled impacts come from regressions that control for a full set of strata dummies to reflect the differential award rates across target colleges and cohorts. Appendix Table A2 reports sample sizes for each follow-up period.

\footnotetext{
${ }^{6}$ The primary considerations are historic precedent and physical capacity constraints at the NU Learning Communities.

${ }^{7}$ Starting in 2013, STBF advertised the scholarship by sending e-mail and print letters to Nebraska ACT testtakers who reported family incomes less than $\$ 100,000$. In addition, the Foundation worked with high school guidance counselors to identify eligible students who were not submitting applications.

${ }^{8}$ Here and throughout our analysis, we exclude fewer than 25 students who were less than 17 years old when they applied for STBF aid.
} 


\subsection{Data and Descriptive Statistics}

Data for this project come primarily from the STBF scholarship application, the administrative records of Nebraska's public colleges, and the National Student Clearinghouse (NSC). The STBF scholarship application provides a rich set of baseline characteristics, including high school transcripts, ACT scores, and detailed demographic and financial information from federal Student Aid Reports. Prior to 2014, the application did not ask students to report race, so we obtained race data from state driver's license records. We supplement the driver's license data with self-reported race in later cohorts.

More than 90 percent of applicants who enrolled in college attended Nebraska public institutions. These colleges and universities provided information on their students' enrollment, financial aid packages, and academic outcomes. To capture enrollment at private and out-of-state colleges, we supplement school-provided records with data from the NSC, which captures 92 percent of enrollment nationwide (Dynarski, Hemelt and Hyman 2015). The data appendix provides additional information about data sources and processing.

STBF applicants are substantially poorer than the general population of Nebraska high school seniors. This can be seen in the first two columns of Table 1, which compare descriptive statistics for eligible scholarship applicants and 12th grade students statewide. Buffett applicants are also disproportionately female and nonwhite. Applicants' ACT scores mirror the average among ACT test-takers in Nebraska, though test-taking rates among STBF's college-bound applicants exceed the state average.

Consistent with STBF's scoring criteria, the guaranteed award winners have higher grades and ACT scores and lower family incomes than the rest of the applicant pool, results that can be seen in column 3 of Table 1. Nearly half are nonwhite, and half are first-generation college students. At the other end of the rankings, students disqualified before random assignment had lower academic achievement but otherwise look similar to the eligible sample.

Randomized students had average annual family incomes near $\$ 47,000$ and Expected Family Contributions just under $\$ 3,000$. They are slightly over two-thirds white, 62 percent female, and averaged B+ grades in high school. Just over one in three had a parent with a bachelor's degree at the time of application. Random assignment successfully balanced the characteristics of treated 
and control applicants in the experimental sample, as Table 1 confirms. Column 6 reports strataadjusted differences in treated and control means with standard errors in parentheses.

Our analysis reports results separately for students targeting two- and four-year colleges. These target college strata are an important feature of the research design and a strong predictor of enrollment outcomes. As shown in Appendix Table A3, students who target community colleges have lower grades and test scores and are less likely to have college-educated parents than students targeting four-year colleges.

\section{How Awards Affected Aid}

We begin by reviewing award effects on students' financial aid packages. This analysis is limited to students who attended Nebraska public colleges because our administrative aid data come from those institutions. Since STBF awards affect where students enroll and, by extension, their inclusion in this sample, the analysis here is potentially subject to selection bias. In practice, however, the effect of awards on enrollment at in-state public colleges is small while the effects on financial aid packages are large. ${ }^{9}$ Though the picture painted here is, in principle, more descriptive than causal, it still provides a useful gauge of the scholarships' impact on financial aid packages.

As a benchmark, the first column of Table 2 describes the first-year financial aid packages of control group students who attended Nebraska public colleges. They incurred almost $\$ 17,000$ in college costs and received about $\$ 12,350$ in total aid, on average. Even without STBF support, these low-income students collected nearly $\$ 7,800$ in grant aid, primarily from need-based public programs. They also accepted roughly $\$ 3,700$ in federal loans and $\$ 830$ in work study wages. These calculations omit private loans, which are underreported in our data. Subsidized public loans are the primary source of borrowed funds for this low-income population.

We estimate the effects of scholarship offers on aid packages using regression models of the form:

$$
A_{i}=\beta S_{i}+\sum_{s, c} \gamma_{s c} d_{i s c}+\Pi^{\prime} X_{i}+\varepsilon_{i}
$$

\footnotetext{
${ }^{9}$ Less than eight percent of control students enrolled at out-of-state or private institutions. Scholarship offers diverted 3.6 percentage points to Nebraska public colleges. These estimates appear in Table 3, which we discuss in greater detail in Section 4.
} 
where $A_{i}$ is the dollar amount of aid that student $i$ received, and $S_{i}$ is an indicator for whether student $i$ was (randomly) offered an STBF scholarship. Since a few students in each cohort turn down Buffett grants for other merit aid, these estimates capture intent-to-treat contrasts between treated and control subjects. The dummies $d_{i s c}$ indicate whether applicant $i$ from cohort $c$ listed school $s$ as her target college. These strata effects adjust for differential award rates by target college and application year. The covariate vector $X_{i}$ includes GPA, EFC, gender, race, and parental education. To the extent that selection into Nebraska public colleges varies with these traits, including $X_{i}$ mitigates the resulting selection bias. In practice, however, controlling for covariates has little effect on the estimates.

STBF award winners received $\$ 7,156$ in Buffett grants, on average, during their first post-award year, as shown in column 2 of Table 2, which reports estimates controlling only for strata dummies, $d_{i s c}$. On net, total grants increased by slightly less $(\$ 6,209)$. The less than one-for-one pass-through reflects a $\$ 951$ decline in institutional awards and private grants with little change in state or federal grants. $^{10}$

STBF aid substantially reduced students' reliance on federal loans and work study wages. Average federal loans fell by $\$ 2,292$, and the share of students accruing any federal debt dropped from 57 to 30 percent. Less than one in five award winners received Federal Work Study, compared with one in three control students. In total, Buffett Scholarship offers increased first-year aid packages by $\$ 3,497$. Column 3 confirms that adding baseline covariates has little impact on these estimates, bolstering the case that these results capture causal effects despite our data limitations.

To estimate the dollar-for-dollar impact of STBF aid on other funding sources, we replace $S_{i}$ in equation (1) with the dollar amount of Buffett aid received. The estimates in column 5 of Table 2 show that each dollar of STBF grant aid increased students' total grants by $\$ 0.85$, while reducing loans by $\$ 0.29$ and work study by $\$ 0.05$, for a net gain of $\$ 0.51$ per dollar awarded. These results capture two countervailing forces. At any given college, scholarship money crowds out aid from other sources, reducing award effects on total aid disbursed. But awards also change where students enroll. In particular, as we explore in detail in Section 4, STBF awards caused many applicants to attend four-year schools instead of less costly community colleges. The first row of

\footnotetext{
${ }^{10}$ Schools must apply federal grants toward aid packages before all other sources, so federal grants do not typically respond to variation in private aid received.
} 
Table 2 documents this shift: every dollar of Buffett aid increased average costs of attendance by $\$ 0.29$. Though four-year colleges cost more, they also provide more grant aid. Control students attending four-year colleges received $\$ 9,114$ in grants, on average, more than double the average grant aid among control students at two-year schools. Scholarship money therefore "crowds in" aid by shifting students to more expensive schools that offer more financial aid.

To disentangle the crowd-out and crowd-in effects, columns 4 and 6 of Table 2 (labeled "campus adjusted") report estimates from a version of equation (1) that includes campus controls, a set of variables which count the number of full-time semesters attended at each campus in the first postaward year. These campus-adjusted regressions measure the extent to which Buffett aid crowds out other funding at a given school. Holding enrollment behavior constant, Buffett aid has no effect on year one costs incurred, and yet each Buffett dollar reduces other grant aid by $\$ 0.29$, an effect that's nearly twice as large as the crowd out estimated without campus controls. ${ }^{11}$ These results should be interpreted cautiously, since campus-adjusted regressions combine causal effects on aid packages for students whose enrollment is invariant to award offers with compositional effects that result from treatment-induced changes in college attended. Nevertheless, the observable covariates have little effect on these estimates. The campus-controlled estimates therefore provide reasonable evidence that Buffett awards dramatically increase students' financial resources.

\section{Enrollment Effects}

Because students targeting two- and four-year colleges have such distinct paths through college, we analyze the scholarships' effects on these groups separately, in Sections 4.1 and 4.2. After presenting the aggregate award impacts by target college, we analyze the differential effects of awards across demographic subgroups in Section 4.3.

\subsection{Enrollment Effects in the Two-Year College Strata}

Almost all STBF applicants attend college in the first year after high school whether or not they win Buffett awards. This fact is apparent in Figure 1, which plots enrollment rates by treatment

\footnotetext{
${ }^{11}$ The crowd-out rate for total grants was similar in year two $(\$ 0.25)$ and year three $(\$ 0.24)$, which indicates that STBF scholarships maintain their value as students progress in school. Other aid programs often shift students from grant aid to loans after the freshman year (Sharpe 2016).
} 
status and target college. Even without Buffett aid, 90 percent of control applicants who targeted community colleges enrolled at some institution in the fall of year one, ${ }^{12}$ as the grey line in Panel A indicates. STBF awards increased initial enrollment in this group by a statistically significant five percentage points. This estimate and others in Figure 1 come from regressions of binary enrollment indicators on the award offer and strata dummies described in equation (1), though unlike the financial aid analysis, these regressions include all randomized applicants in the two-year college strata, not just those who enrolled at Nebraska public colleges. Whiskers indicate 95 percent confidence intervals for the estimated treatment effects.

Although students in the two-year strata indicated that they aspired to attend community colleges, some opted to enroll at four-year schools after receiving scholarship support. Table 3 documents this shift across institutions. Nearly all of the five point increase in total enrollment, shown in the first row of column 4, comes from increased enrollment at four-year colleges. Admissions records from the University of Nebraska reveal that many of the students who altered their stated college plans didn't apply to four-year schools until after receiving Buffett aid. Award offers boosted applications to UNO, for example, from eight to 13 percent in the two-year strata, as Appendix Table A4 reports. Scholarship winners were no more likely to be admitted conditional on applying, however; UNO admitted 77 percent of both treated and control applicants from the two-year college strata. ${ }^{13}$ The mechanism that motivates some Buffett Scholars to alter their college plans is yet unknown. Award winners may interpret scholarship offers as positive signals of their college aptitude and revise their enrollment goals. Another explanation is financial: STBF's award scheme implicitly subsidizes shifting from two- to four-year schools since awards cover tuition at any Nebraska public college, and four-year schools are more expensive - both in total and on a per-credit basis.

Like many state aid programs, Buffett awards diverted some enrollment from out-of-state and private schools into Nebraska public colleges, though there was little scope for shifting on this margin in the two-year strata. Just four percent of control students enrolled outside the Nebraska

\footnotetext{
${ }^{12}$ In keeping with the the Federal Student Aid year, we define post-award years to run from July 1 through June 30. We divide each post-award year into fall and spring periods, where fall runs from July through December, and spring runs from January through June.

${ }^{13}$ It's unlikely that scholarship applicants who intend to enroll at UNO misreport their college plans to increase their chances of winning Buffett awards. The average award rate was 47 percent for the two-year strata and 54 percent for UNO, as the sample counts in Appendix Table A1 indicate. We are still working to collect admissions records from UNL, the most selective NU campus. However, the vast majority of two-year strata students who matriculate at four-year schools attend UNO, owing, perhaps, to its rolling admission deadlines and proximity to Nebraska's largest community college.
} 
public college system, and awards reduced that rate to two percent, as shown in Panel B of Table 3.

Both treatment and control group enrollment declined modestly during the second follow-up year, but thereafter these groups' enrollment paths diverged. Many control students left school during year three, and by year four fall, just 28 percent were still enrolled in college. Though dropout also accelerated in the treated pool, Buffett awardees were nearly twice as likely to extend their studies beyond three years: more than half enrolled in the fall of year four. Panel A of Figure 1 plots these trends, and Table 4 reports the corresponding estimates. ${ }^{14}$

Award winners' extended enrollment came at the expense of associate's degree completion. This result appears in the last two columns of Table 4, which disaggregates year-four enrollment by degree status. The top row reports the total enrollment rate: 28 percent of control applicants enrolled in the fall of year four, and 72 percent did not. Roughly half of those not enrolled earned associate's degrees before leaving school. Treated students, in contrast, were 21 points less likely to complete terminal associate's degrees. Instead, many treated applicants transferred to four-year schools without first earning two-year credentials: award offers increased the share of students attending four-year institutions without any degree from 8.5 to 20 points. STBF's continuation requirements may encourage these transfers because awards only cover three years of study at community colleges. Students who wish to maintain their scholarships must therefore transfer to four-year colleges by the fall of year four. The point estimate indicates that scholarships may have decreased the number of students who dropped out before completing any degree (by 5.4 percentage points), but this figure is imprecisely estimated.

\subsection{Enrollment Effects in the Four-Year Strata}

STBF applicants who targeted four-year schools were even more likely to enroll in college than their two-year strata counterparts, even without Foundation support. More than 96 percent of control applicants attended college in the fall of year one, and awards boosted this rate by a statistically significant three percentage points. Panel B of Figure 1 plots these enrollment rates.

\footnotetext{
${ }^{14}$ Because the results for initial enrollment pool data from all four cohorts, they are more precisely estimated than the impacts on longer-run enrollment. Appendix Table A5 shows that the underlying cohort-specific enrollment rates are not significantly different from the pooled estimates in Figure 1.
} 
Students in the four-year strata also applied to a wider range of institutions than their community college-bound peers, so awards had more scope to influence these students' college choice. Scholarship offers decreased the fraction of students attending out-of-state or private schools from eight to four percent, as columns 5 and 6 of Table 3 report. Importantly, however, and in contrast with other state merit aid programs (see Cohodes and Goodman 2014), the shift to Nebraska public schools was concomitant with a shift toward more-selective institutions. Specifically, STBF awards increased the proportion of students attending selective colleges (with admission rates below 75 percent) by four points. The fraction of students attending moderately-selective four-year schools (with admissions rates between 75 and 90 percent) increased by a similar amount. At the same time, awards reduced the share attending community colleges from nine to three percent. ${ }^{15}$

Though scholarships had only modest effects on initial enrollment in the four-year strata, awards substantially reduced dropout in the critical transition between freshman and sophomore years. Nearly half of all dropout from bachelor's degree programs occurs at this juncture (Kena et al. 2015). ${ }^{16}$ In STBF's relatively high-achieving applicant pool, scholarship offers boosted sophomore enrollment by seven points, ensuring that 96 percent of treated students enrolled in year two. The impact on four-year college going was even larger: STBF awards increased four-year enrollment by 13 points in year two fall. These results appear in column 4 of Table 5 , which documents institutional shifting in the four-year strata in a format similar to Table 4.

Importantly, while many interventions produce short-lived gains, STBF award impacts appear to be cumulative. By the fall of year four, awards increased total enrollment by 14 points, from 74 to 88 percent. Nearly all students were attending bachelor's degree-granting institutions by the fourth follow-up year. Less than 10 percent of both treated and control students were still enrolled at two-year institutions.

\footnotetext{
${ }^{15}$ Most STBF applicants who enrolled outside the Nebraska public college system attended private schools in the Midwest. The top five schools attended outside the Nebraska public college system were Nebraska Wesleyan University, Creighton University, Hastings College, Concordia University, and Midland University, all religiously-affiliated private institutions in Nebraska.

${ }^{16}$ Just 80 percent of all first-time, full-time undergraduates at bachelor's degree-granting institutions return for a second year, while 60 percent complete bachelor's degrees within six years. Freshman retention rates at the University of Nebraska hover near the national average, ranging from 77 percent at UNO to 84 percent at UNL in 2014 (U.S. Department of Education 2014).
} 


\subsection{Subgroup Impacts: Race, Family Background, and College-Preparedness}

Within the four-year strata, STBF awards generated especially large enrollment gains for demographic groups with high expected dropout rates in the absence of treatment. ${ }^{17}$ Figure 2 documents this variation in program impacts by race and parental education, both strong predictors of enrollment and retention. Nonwhites in the control group were less likely to attend college than were their white peers. More than 98 percent of white applicants enrolled without Foundation support compared with 94 percent of nonwhite students. Award offers equalized their initial enrollment so that more than 99 percent of award winners from both groups attended college in year one. Four years out, awards narrowed the race gap in enrollment from twelve points to just seven. Panels $\mathrm{C}$ and D document a similar pattern by parental education.

Figure 3 reveals even more striking patterns in program impacts by academic preparation. The dots in Panels A and B show estimated impacts on year-two fall enrollment for deciles of high school GPA, and the solid lines plot fitted values from regressions that estimate the linear interaction between award status and GPA. Dashed lines plot 95 percent confidence intervals for the linear fitted values. Panel A shows that award offers boosted year-two enrollment by 23 points in the bottom decile, from 74 to 97 percent. These students, with average high school GPAs of 2.7, would be ineligible for many state merit aid programs, which often require GPAs of 3.0 (Fitzpatrick and Jones 2016). At the same time, scholarships had almost no measurable impact on persistence for the top-performing students who receive most merit aid. Among students with high school GPAs above 3.5 - fully half the randomized sample - awards increased year-two fall enrollment by just three points. ${ }^{18}$ The GPA gradient for award impacts on four-year college enrollment was even more pronounced, as Panel B illustrates. Scholarships increased the share of bottom-decile students attending four-year schools in sophomore year by a whopping 40 points, with no effect at the top end of the grade distribution. Appendix Figure A1 documents similar patterns using ACT scores to measure college readiness in lieu of high school GPA. These results are consistent with Dynarski's

\footnotetext{
${ }^{17}$ We restrict our subgroup analyses to students who targeted four-year colleges since the community college sample is currently too small to support precise comparisons across subgroups. In time, additional cohorts will facilitate similar investigations in the two-year strata.

${ }^{18}$ Appendix Table A6 compares OLS and logit estimates of effects in subgroups. Logit marginal effects are virtually indistinguishable from the corresponding OLS estimates.
} 
(2004) argument that state aid programs with more stringent academic standards may exclude many of the students who respond most to financial aid.

Though award impacts vary by race, parental education, and academic achievement, we see less evidence of differential impacts by financial need. Panels C and D of Figure 3 plot award effects by Expected Family Contribution (EFC), the metric that determines eligibility for STBF grants and federal aid programs. There is no clear gradient in award impacts by financial need. ${ }^{19}$ Appendix Figure A1 documents similar patterns using family income to gauge financial need.

We summarize the variation in award impacts by showing how treatment effects vary with a single index of expected college enrollment. Such "endogenous stratification" estimates are best computed using leave-out fitted values, as Abadie, Chingos and West (2013) detail. (Otherwise, enrollment outcomes are mechanically correlated with predicted enrollment, which may bias estimates of causal effects.) In this case, we use the control group data to estimate the relationship between outcome $Y_{j}$ and covariates $X_{j}$ in leave-out samples that omit each observation $i$ :

$$
Y_{j}=\pi_{(-i)}^{\prime} X_{j}+\varepsilon_{j} ; \quad j \neq i
$$

The vector $X_{j}$ contains gender, race, parental education, EFC, and high school GPA — all strong predictors of enrollment and persistence. The resulting leave-out fitted values are given by

$$
\hat{Y}_{i}=\hat{\pi}_{(-i)}^{\prime} X_{i}
$$

Estimates of STBF award effects conditional on expected enrollment, $\hat{Y}_{i}$, appear in Figure 4. As in the previous graphs, each dot represents a decile of expected enrollment, and the solid lines plot the corresponding linear fitted values. Since nearly all control applicants in the four-year strata enroll in year one, the deciles of expected enrollment range from just .89 to 1. Even so, award offers increased initial enrollment in the bottom decile by more than 10 points, ensuring that nearly all scholarship recipients enrolled in college. By year two, baseline covariates predict that roughly one in four students in the bottom decile would not be enrolled in college absent scholarship support. Scholarships boosted their enrollment rate by more than 20 points. Award impacts in years three and four exhibit similar patterns, with enrollment impacts of over 40 percentage points for the lowest decile by year four.

\footnotetext{
${ }^{19}$ Among applicants with EFCs low enough to qualify for Buffett aid, those with EFCs above $\$ 6,000$ qualify for fewer forms of other need-based aid, including federal Pell grants and institutional grants.
} 
Together, these subgroup analyses highlight the challenging trade-off between rewarding students' past achievement and increasing program impacts. Students who appear most meritorious based on grades and test scores are also those most likely to persist in college absent scholarship support. Conversely, applicants who appear more likely to struggle in college respond more dramatically to merit aid when they are fortunate enough to receive it.

\section{Distinguishing Financial Aid and Learning Community Effects}

Roughly 80 percent of scholarship winners in the four-year strata enroll at University of Nebraska campuses, where Buffett Scholars participate in STBF Learning Communities (LCs) during freshman and sophomore years. Award impacts in the four-year strata therefore combine the effects of financial support with the effects of LC services. ${ }^{20}$ An aid-only treatment arm, known to applicants as the College Opportunity Scholarship (COS), allows us to estimate the marginal effect of LC participation. COS awards offer the same grant support as STBF scholarships but exclude access to LC services. ${ }^{21}$ COS awards were introduced in the second experimental cohort and were only offered in the NU strata; guaranteed award winners and those in the state and community college strata received full STBF scholarships throughout the study. The COS sample is therefore much smaller than the sample for the main treatment arm.

Figure 5 offers a preliminary look at enrollment effects for the aid-only scholarships. Averaging data across all NU campuses, both STBF and COS awards generated positive enrollment gains in each post-award year (Panel A). Traditional STBF award impacts were marginally higher in all years, but the gaps were not statistically significant. Panels B-D reveal emerging heterogeneity across NU campuses. Though imprecise, these estimates suggest that LC services at UNO roughly double the impact of aid alone. COS grants boosted sophomore enrollment by six percentage points, less than the 12 point gain from full awards. At UNL and UNK, however, there is no evidence that LC services increase enrollment rates.

As in all analyses of site-specific treatment effects, it can be difficult to discern whether these patterns reflect variation in LC service quality across sites or in the populations targeting each

\footnotetext{
${ }^{20}$ Award winners in the community college and four-year state college strata must also participate in LCs if they enroll at NU as freshmen, though just seven percent exercise that option.

${ }^{21}$ The LCs operated at full capacity throughout the study. COS awards increased the total number of scholarship recipients without reducing LC enrollment.
} 
campus. As Appendix Table A3 details, UNO serves a disproportionate fraction of students with the biggest documented gains from full awards: racial minorities, first-generation college-goers, and students with lower grades and test scores. UNL and UNK, in contrast, attract students with higher expected retention in the absence of treatment. The variation in Figure 5 may therefore capture heterogeneity across students rather than across campuses. Indeed, Figure 6 shows that splitting the sample by high school GPA instead of campus shows no differential impacts for students with GPAs at or above the sample median (3.5), but markedly different, albeit noisy, impacts on students with below median GPAs. These findings suggest that LC services may boost persistence for students with lower GPAs despite their small aggregate effects. With additional follow-up data, these results will become more precise and conclusive.

\section{Preliminary and Projected Completion Effects}

A complete picture of award impacts on bachelor's degree completion is still one or two years away. In keeping with nationwide trends, less than one in three students at Nebraska's four-year public colleges graduates within four years. After six years, however, graduation rates more than double, ranging from 37 to 67 percent across Nebraska public institutions. (U.S. Department of Education 2015).

Like their peers, many Buffett applicants in the oldest randomized cohort were still enrolled but did not earn bachelor's degrees by the end of year four. Table 6 summarizes their year-four graduation rates. In the community college strata, slightly more than half (52 percent) of control group students earned associate's degrees by the end of year four. Scholarships decreased this rate by an insignificant but economically meaningful 12 percentage points. This reduction in associate's degrees may ultimately be offset by an increase in bachelor's degrees. Although few students in the two-year strata have earned bachelor's degrees to date (5.6 percent in the control group), our estimates, while imprecise, suggest that scholarships have roughly doubled this number to 11.0 percentage points. Scholarships also increased the share of students enrolled in four-year colleges who have not yet earned bachelor's degrees from 15 to 23 percentage points. The total effect of scholarships on degree completion for this group will depend on how many of these students eventually complete BAs. 
Scholarships also decreased degree completion in the four-year strata by the end of year four. While only five percent of control students earned associate's degrees by the end of year four, 28 percent completed bachelor's degrees, as shown in Table 6. Scholarships reduced these completion rates by 2.4 and 5.9 points, respectively. Buffett Scholars' lower on-time graduation rates may reflect the scholarship's terms. STBF provides up to five years of funding, so award winners likely face less financial pressure to graduate in four years than other students do. In keeping with this reasoning, scholarship winners were much more likely to be enrolled in four-year colleges without earning degrees by the end of year four ( 57 vs. 39 percentage points).

Results from the 2012 cohort to date show that scholarships have increased the share of students who are on track to earn bachelor's degrees while simultaneously depressing the number of degrees completed in four years. It remains to be seen which of these countervailing forces will dominate in the long run. To provide a statistical preview of future graduation results, we use data from the STBF's 2011 application cohort, the last cohort of students who applied before the experiment began. ${ }^{22}$ Though these students were not subject to random assignment, outcomes for successful and unsuccessful scholarship applicants from this cohort may, in conjunction with our experimental estimates, be informative about the trajectory of experimental cohorts.

We use Kline's (2011) selection-correction procedure to adjust for non-random assignment of award offers in the non-experimental cohort. The Kline method relies on a linear model for potential outcomes given baseline covariates,

$$
Y_{i}^{d}=\mathbf{X}_{i}^{\prime} \beta^{d}+\varepsilon_{i}^{d}
$$

for $d \in\{0,1\}$. Under a mean independence assumption,

$$
\mathbb{E}\left[\varepsilon_{i}^{d} \mid \mathbf{X}_{i}, D_{i}\right]=0
$$

an ordinary least squares (OLS) regression among the controls identifies $\beta^{0}$ :

$$
\beta^{0}=\mathbb{E}\left[X_{i} X_{i}^{\prime} \mid D_{i}=0\right]^{-1} \times \mathbb{E}\left[X_{i} Y_{i} \mid D_{i}=0\right]
$$

which captures the relationship between covariates and potential outcomes absent scholarship support. If the same mapping from covariates to untreated outcomes holds among award winners, then

\footnotetext{
${ }^{22}$ As with the subgroup analysis, we restrict the projection estimates to the four-year strata due to power limitations in the community college strata.
} 
the average effect of treatment on the treated (TOT) is

$$
\mathbb{E}\left[Y_{i}^{1}-Y_{i}^{0} \mid D_{i}=1\right]=\mathbb{E}\left[Y_{i}^{1} \mid D_{i}=1\right]-\mathbb{E}\left[X_{i} \mid D_{i}=1\right]^{\prime} \beta^{0}
$$

Kline shows that this hybrid procedure outperforms regression in replicating the experimental effects of federal job training programs in LaLonde's (1986) classic analysis.

We find support for the hypothesis that scholarships will ultimately boost bachelor's degree completion among students who were randomly assigned scholarships. The top panel of Figure 7 compares estimated effects on bachelor's degree completion for the 2012 experimental sample with estimates for the non-randomized 2011 cohort. As in Kline's replication exercise, selectioncorrected estimates from the non-experimental data faithfully replicate the experimental findings. The experimental and non-experimental estimates in Panel A are similar through the end of year four, where both samples show a five to seven point deficit in graduation rates for award winners. By the end of year five, however, 2011 award winners were eight percentage points more likely to complete bachelor's degrees than control applicants. The plotted estimates control for high school GPA, EFC, gender, race, and parental education, but more parsimonious models produce similar results. ${ }^{23}$

To adjust for potential differences in sample composition across cohorts, we reweight the 2011 Kline estimates by the distribution of covariates in the randomized sample and plot the resulting projections in Panel B. Reweighting leaves the bottom line unchanged. These graphs suggest that Buffett Scholars eventually convert enrollment gains into bachelor's degrees even though awards increase time to completion for some. Experimental estimates of award impacts on five-year graduation rates will be available in the summer of 2017 .

\section{Summary and Conclusions}

STBF scholarships generated large gains in college enrollment four years after award receipt. Modest effects on initial enrollment have grown as the scholarship increased college persistence. Though apparent in our earlier working paper, these patterns have become clearer as the followup window has lengthened and more cohorts have boosted precision. Estimated enrollment gains

\footnotetext{
${ }^{23}$ Appendix Table A7 explores the robustness of these results to alternative control functions.
} 
remain largest for nonwhite applicants, first-generation college-goers, and students with the lowest grades and test scores in the eligible applicant pool. These findings highlight the paradox of merit aid: awards based on past achievement are likely to generate smaller gains than awards made to applicants who appear less college-ready.

Awards have also shifted students from two- to four-year schools, reducing associate's degree completion in the process. The long-run effects of reductions in two-year credentials on terminal degree completion will likely depend on whether scholarship recipients convert their extended enrollment at four-year institutions into bachelor's degrees. In the short run, Buffett scholarships appear to have reduced on-time graduation rates at four-year colleges, likely because these scholarships provide up to five years of funding. Analysis of outcome data from a pre-experimental cohort suggests that this effect is likely to be transitory: we project that scholarships will raise degree completion after five years.

Our results are preliminary and limited to the outcomes available within the first four years of award receipt. As the current cohorts age and new cohorts enter the study, we expect to examine effects on college completion and sharpen our estimates of differential effects across subgroups. Evidence on the relative contribution of financial support and Learning Community services should also grow more conclusive. Ultimately, we expect to measure how award effects on retention and degree completion influence long-run labor market outcomes. 


\section{References}

Abadie, Alberto, Matthew M. Chingos, and Martin R. West. 2013. "Endogenous Stratification in Randomized Experiments." National Bureau of Economic Research Working Paper 19742, December.

ACT. 2012. "The Condition of College \& Career Readiness 2012." http://www.act.org/content/dam/act/unsecured/documents/CCCR12-

NationalReadinessRpt.pdf (accessed December 14, 2016).

Angrist, Joshua D., David H. Autor, Sally Hudson, and Amanda Pallais. 2014. "Leveling Up: Early Results from a Randomized Evaluation of Post-Secondary Aid." National Bureau of Economic Research Working Paper 20800, December.

Cohodes, Sarah R., and Joshua S. Goodman. 2014. "Merit Aid, College Quality, and College Completion: Massachusetts' Adams Scholarship as an In-Kind Subsidy." American Economic Journal: Applied Economics, 6(4): 251-285.

Dynarski, Susan M. 2004. "The New Merit Aid." In College Choices: The Economics of Where to Go, When to Go, and How to Pay For It. Vol. I, eds. Caroline M Hoxby, 67-93. Chicago: University of Chicago Press.

Dynarski, Susan M., and Judith Scott-Clayton. 2007. "College Grants on a Postcard: A Proposal for Simple and Predictable Federal Student Aid." The Hamilton Project Discussion Paper 2007-01, March.

Dynarski, Susan M., Steven W. Hemelt, and Joshua M. Hyman. 2015. "The Missing Manual: Using National Student Clearinghouse Data to Track Postsecondary Outcomes." Educational Evaluation and Policy Analysis, 37: 53S-79S.

Fitzpatrick, Maria D., and Damon Jones. 2016. "Higher Education, Merit-Based Scholarships and Post-Baccalaureate Migration." Economics of Education Review, 54(October): 155-172.

Kena, Grace, Lauren Musu-Gillette, Jennifer Robinson, Xiaolei Wang, Amy Rathbun, Jijun Zhang, Sidney Wilkinson-Flicker, Amy Barmer, and Erin Dunlop Velez. 2015. 
"Institutional Retention and Graduation Rates for Undergraduate Students." U.S. Department of Education, Institute of Education Sciences, National Center for Education Statistics, Washington D.C.

Kline, Patrick. 2011. "Oaxaca-Blinder as a Reweighting Estimator." American Economic Review: Papers \& Proceedings, 101(3): 532-537.

Lalonde, Robert J. 1986. "Evaluating the Econometric Evaluations of Training Programs with Experimental Data." American Economic Review, 76(4): 604-620.

National Cancer Institute. 2015. "U.S. Population Data - 1990-2015 Expanded Races (White, Black, American Indian/Alaska Native, Asian/Pacific Islander) by Origin (Hispanic, Non-Hispanic)." Surveillance, Epidemiology and End Results (SEER) Program https://seer.cancer.gov/popdata/download.html (accessed January 5, 2017).

Sharpe, Rochelle. 2016. "Why Upperclassmen Lose Financial Aid." New York Times, April 6.

University of Nebraska-Lincoln. 2015. "Budgets for 2015-2016." http://financialaid.unl.edu/budget.html (accessed October 21, 2015).

U.S. Census Bureau. 2014. "American Community Survey (ACS), One-Year Public Use Microdata Sample (PUMS), 2014." (accessed via ftp March 1, 2016).

U.S. Department of Education. 2010a. "Common Core of Data." Institute of Education Sciences, National Center for Education Statistics https://nces.ed.gov/ccd/ (accessed February 4, 2016).

U.S. Department of Education. 2010b. "Private Schools Universe Survey." Institute of Education Sciences, National Center for Education Statistics https://nces.ed.gov/surveys/pss/ (accessed February 4, 2016).

U.S. Department of Education. 2014. "Integrated Postsecondary Education Data System (IPEDS)." Institute of Education Sciences, National Center for Education Statistics https://nces.ed.gov/ipeds/datacenter (accessed March 1, 2015). 
U.S. Department of Education, Institute of Education Sciences, and National Center for Education Stastics. 2015. "College Navegator." https://nces.ed.gov/collegenavigator/ (accessed December 20, 2016).

Weiss, Michael J., Mary G. Visher, Evan Weissman, and Heather D. Wathington. 2015.

"The Impact of Learning Communities for Students in Developmental Education: A Synthesis of Findings from Randomized Trials at Six Community Colleges." Education Evaluation and Policy Analysis, $37(4):$ 520-541. 
Figure 1

Award Effects on College Enrollment

\section{A. Two-Year College Strata}

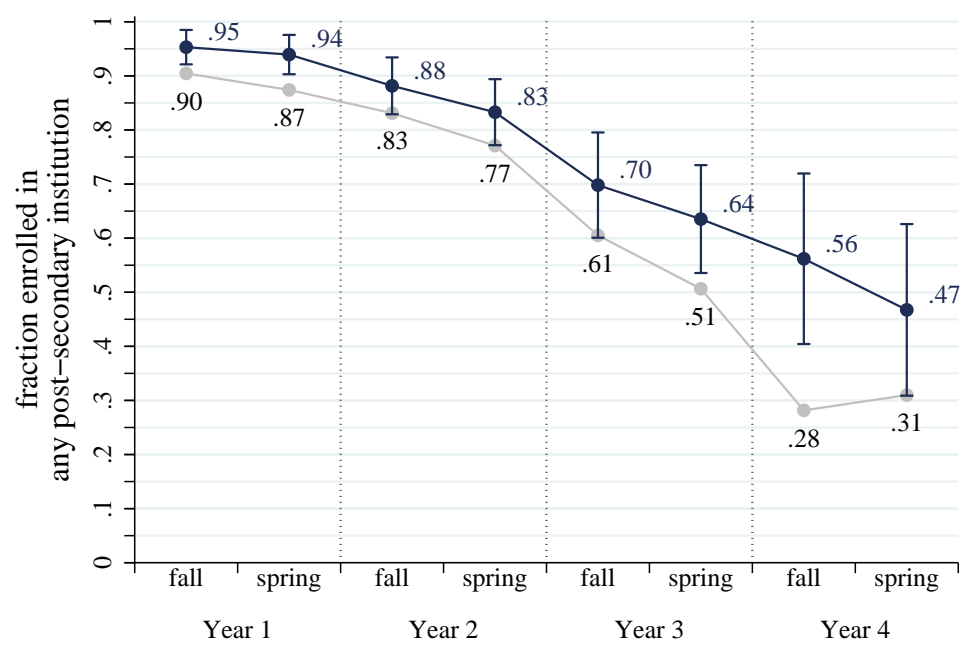

years since high school graduation

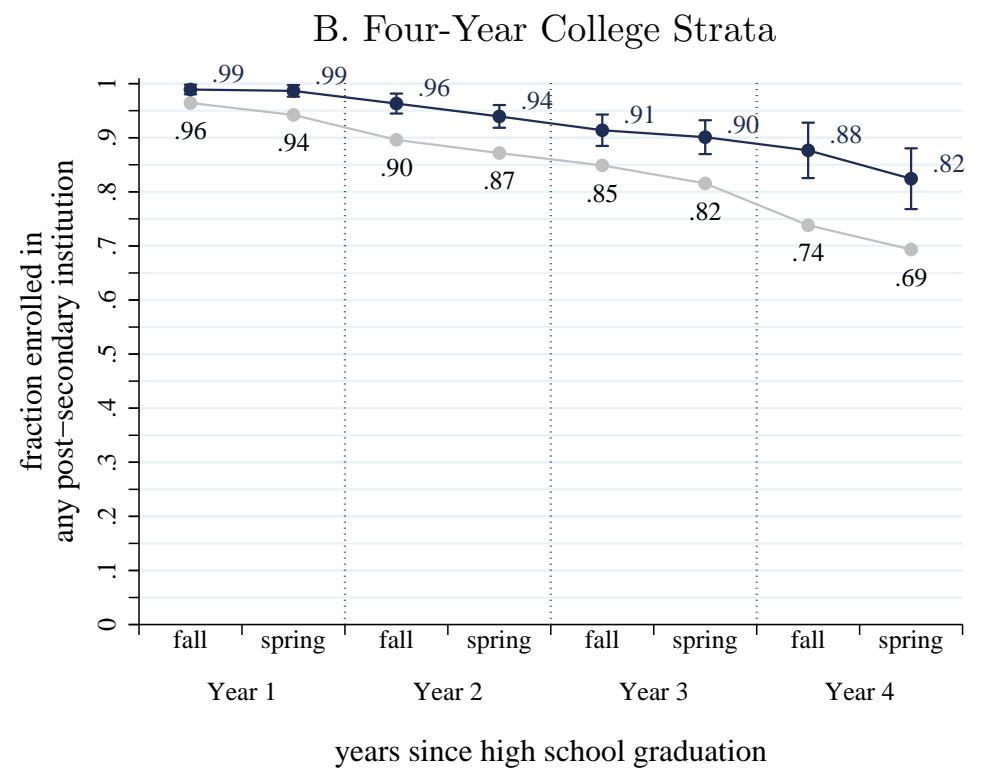

$\longrightarrow$ STBF Treated

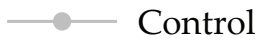

Notes: Panel A presents enrollment rates by treatment status for students who targeted two-year colleges. The grey line plots the enrollment rate for control applicants, and the blue line plots the sum of the control mean and strataadjusted treatment effect for traditional STBF scholarship winners. Whiskers indicate 95 percent confidence intervals. Panel B plots enrollment rates for students who targeted four-year colleges. Samples for each time horizon use data from all available applicant cohorts: 2012-2015 for year one; 2012-2014 through year two; 2012-2013 through year three; and 2012 only for year four. Fall includes any enrollment that occurs between July 1 and December 31, and spring runs from January 1 through June 30. 
Figure 2

College Enrollment Rates by Race and Parental Education

in the Four-Year College Strata
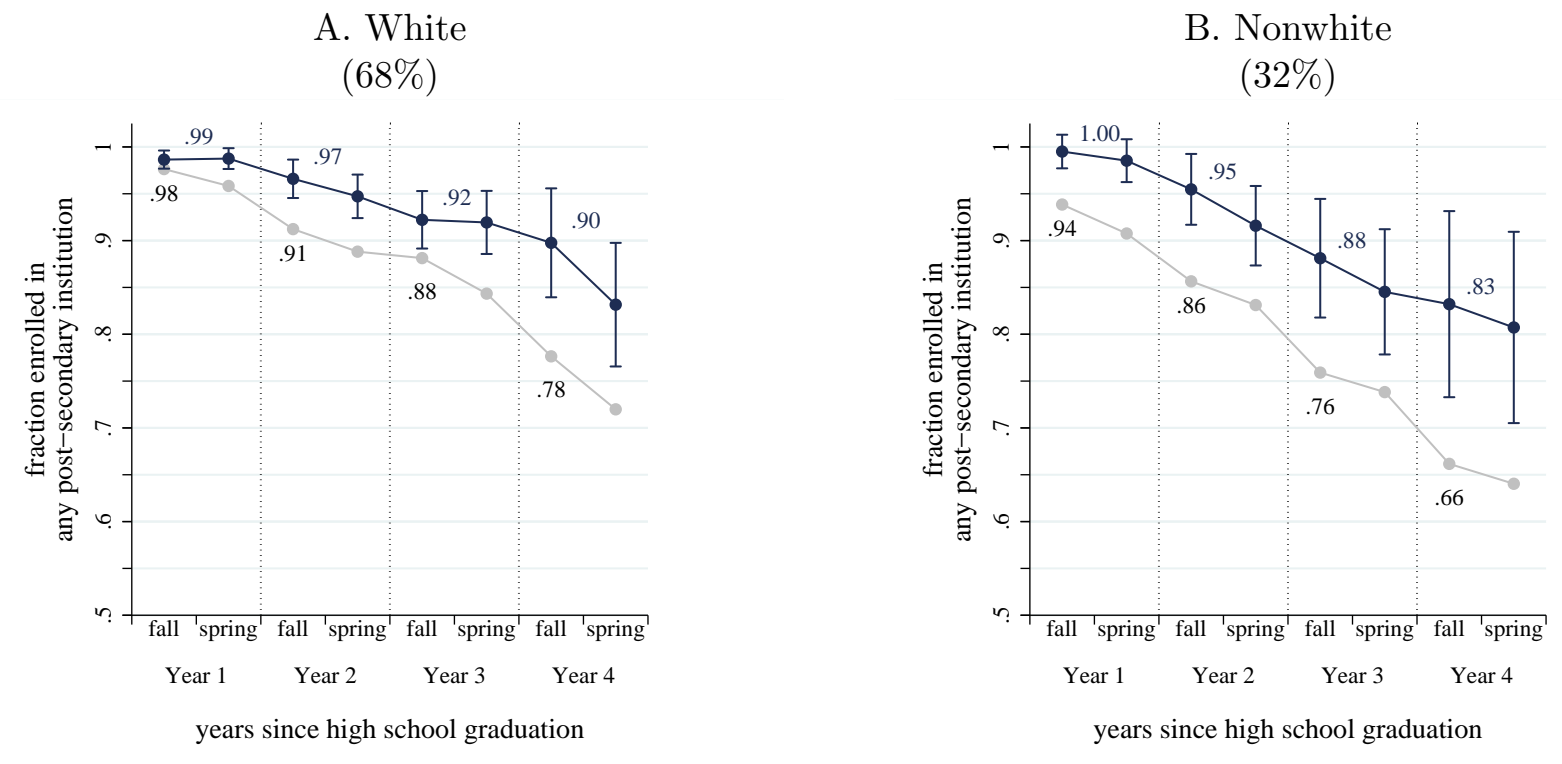

C. At Least One Parent

Earned a Bachelor's Degree

$(35 \%)$
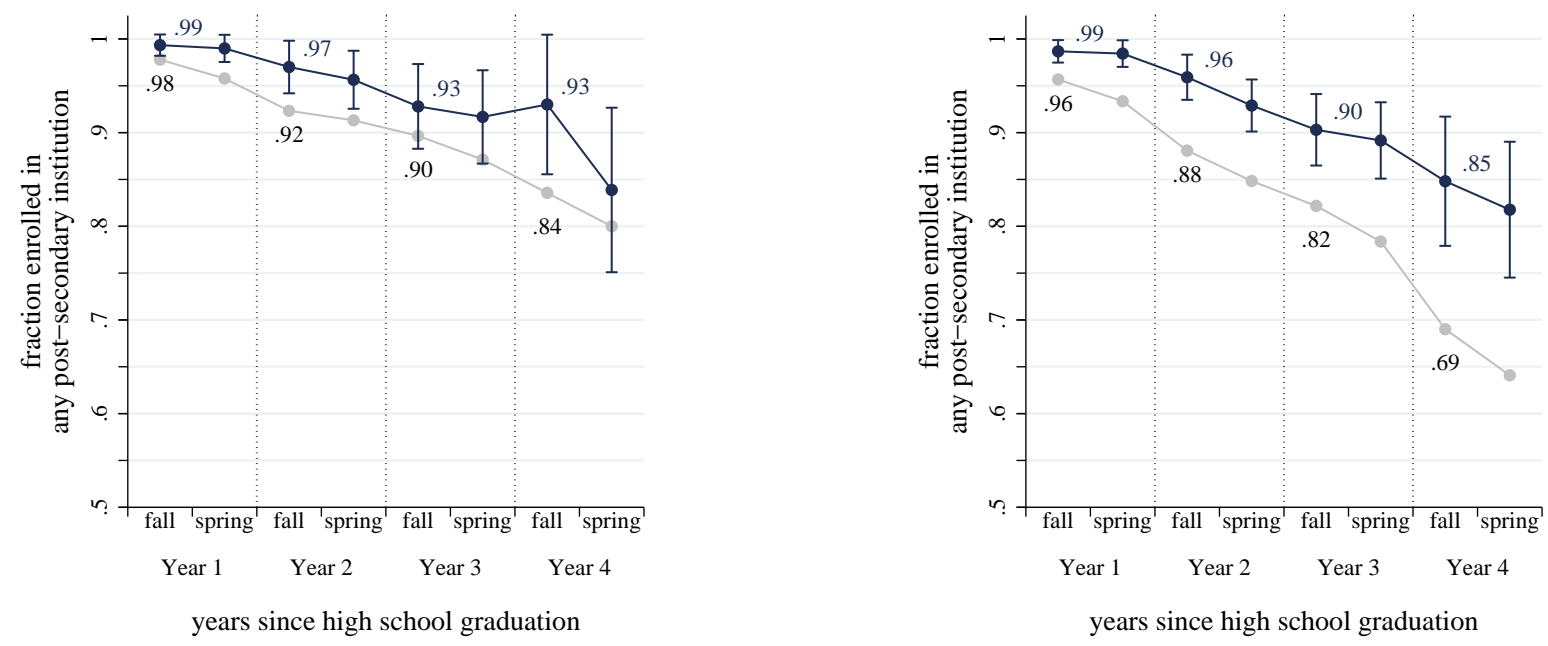

$\longrightarrow$ STBF Treated $\longrightarrow$ Control

Notes: These graphs summarize how award effects on enrollment differ by race and parental education of scholarship applicants. Grey lines plot enrollment rates for control applicants, and blue lines plot the sum of control means and strata-adjusted treatment effects for traditional STBF scholarship offers. Whiskers indicate 95 percent confidence intervals. Samples vary across time horizons as defined in Figure 1. Roughly 42 percent of white applicants had at least one parent with a bachelor's degree, compared with just 19 percent of nonwhite students. 
Figure 3

Effects on Year-Two Fall Enrollment by GPA and EFC in the Four-Year College Strata

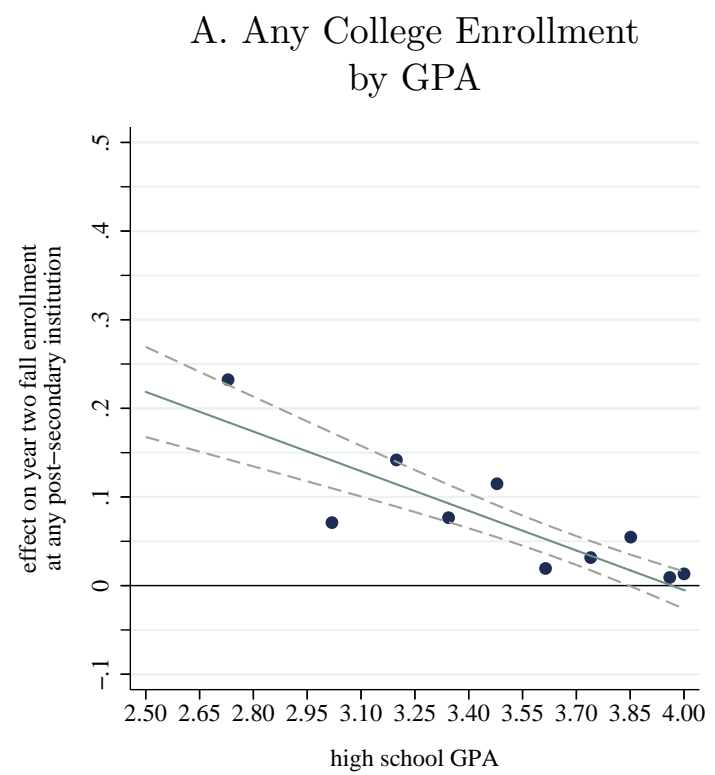

\section{B. Four-Year College Enrollment by GPA}

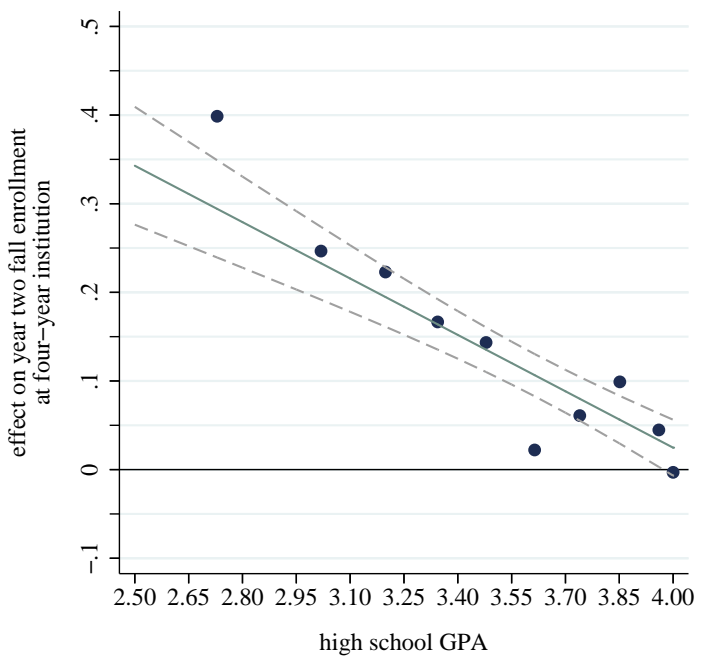

C. Any College Enrollment

by EFC

D. Four-Year College Enrollment by EFC
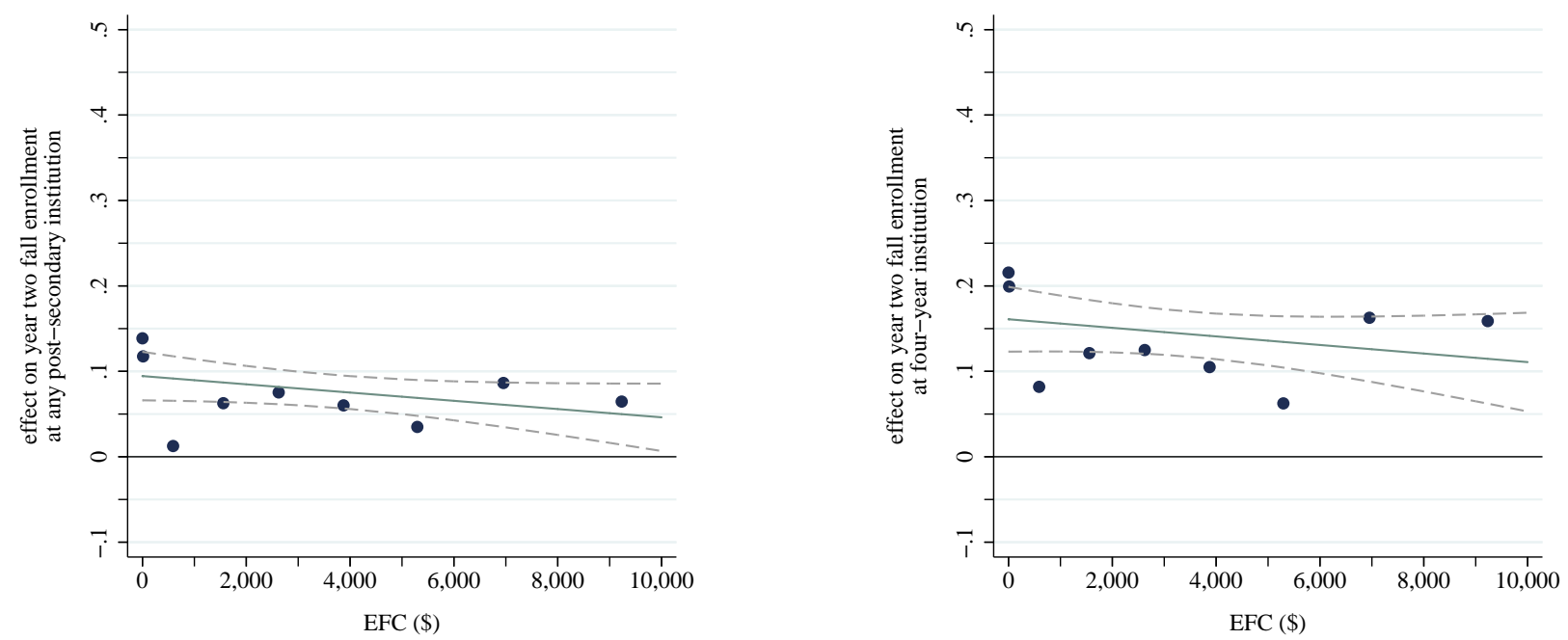

Notes: These graphs document how award effects vary with applicants' high school GPA and Expected Family Contribution (EFC). The outcome in each panel is year-two fall enrollment. The sample includes applicant cohorts 2012-2014. Dots plot treatment effects of traditional STBF scholarship offers for deciles of the given trait. Solid lines plot fitted values from a regression model that estimates the linear interaction between award status and the given trait. Dotted lines plot 95 percent confidence intervals for the linear fitted values. 


\section{Figure 4}

Effects on Enrollment in the Four-Year College Strata by Estimated Propensity to Enroll

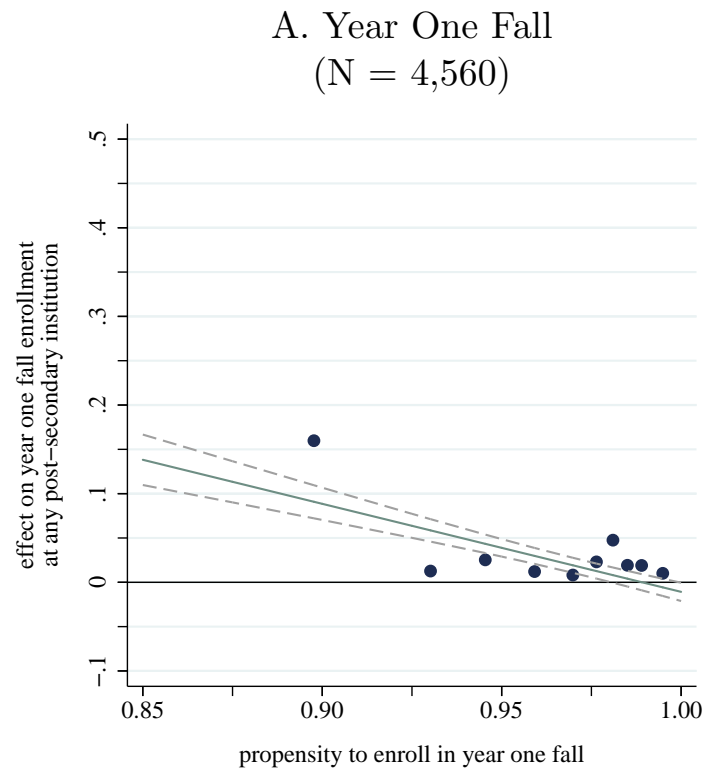

C. Year Three Fall

$(\mathrm{N}=2,024)$

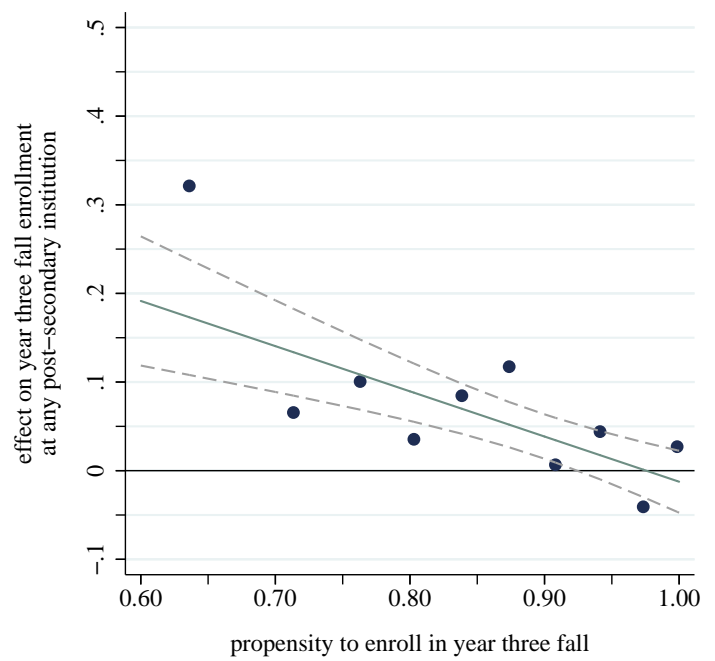

B. Year Two Fall

$(\mathrm{N}=3,219)$

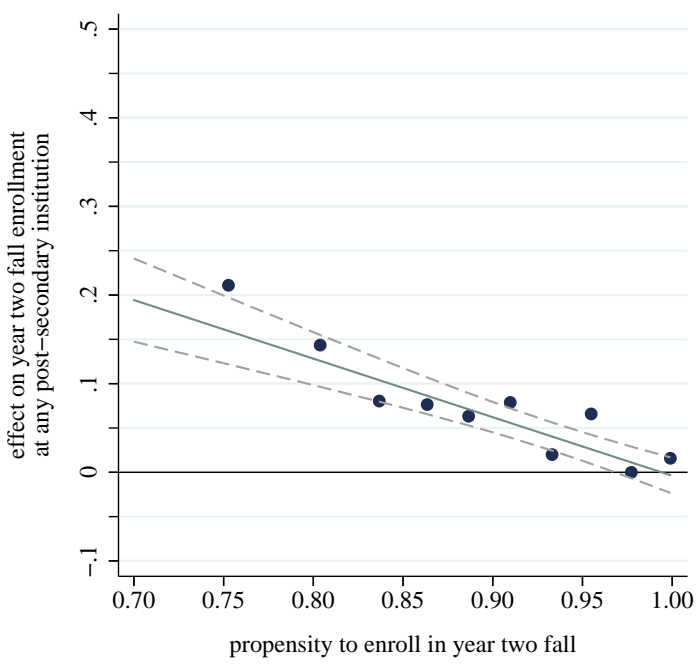

D. Year Four Fall

$(\mathrm{N}=855)$

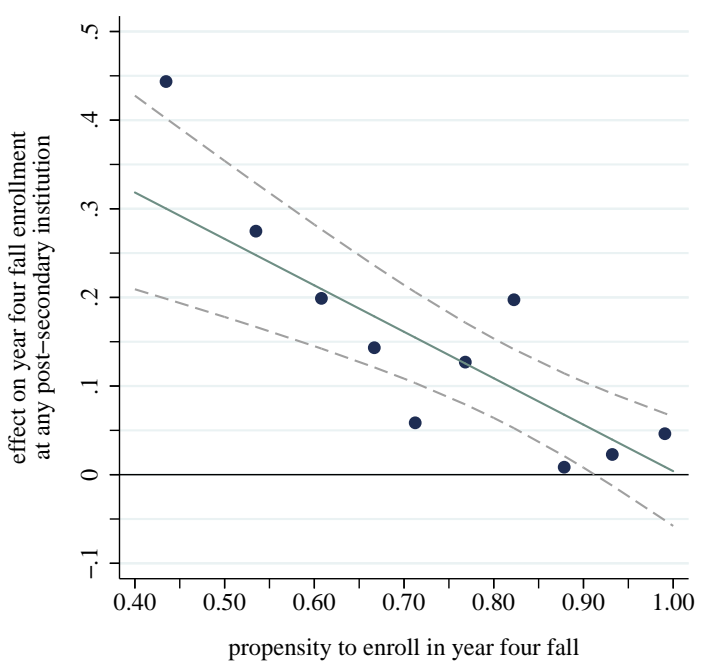

Notes: These graphs summarize how award effects on enrollment vary with applicants' baseline characteristics. The horizontal axis in each plot is propensity to enroll in the given year as a function of gender, race, parental education, EFC, and high school GPA, estimated using the leave-one-out fitted values proposed by Abadie, Chingos and West (2013). Dots plot treatment effect estimates for each decile of expected enrollment, and solid lines plot fitted values from a regression model that estimates the linear interaction between award status and expected enrollment. Dotted lines plot 95 percent confidence intervals for the linear fitted values. Samples vary across time horizons as defined in Figure 1. 


\section{Figure 5}

\section{Comparing Financial Aid Effects With and Without Learning Community Services}

by Intended University of Nebraska Campus

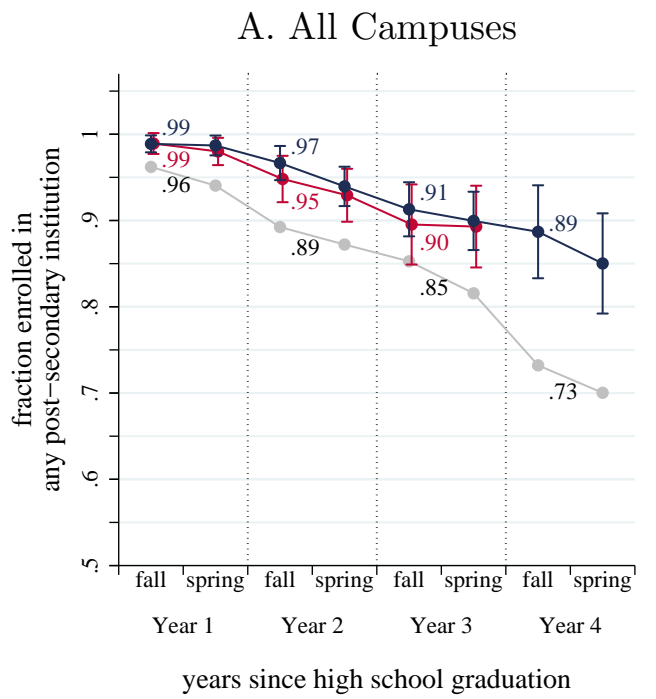

C. Lincoln

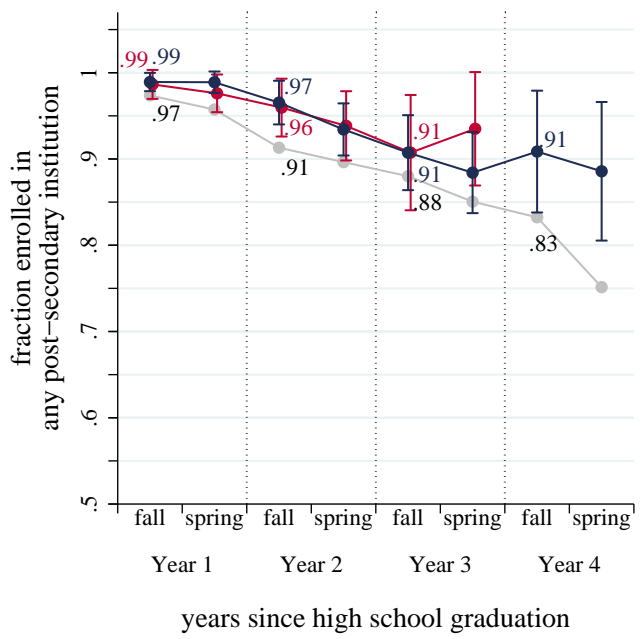

B. Omaha

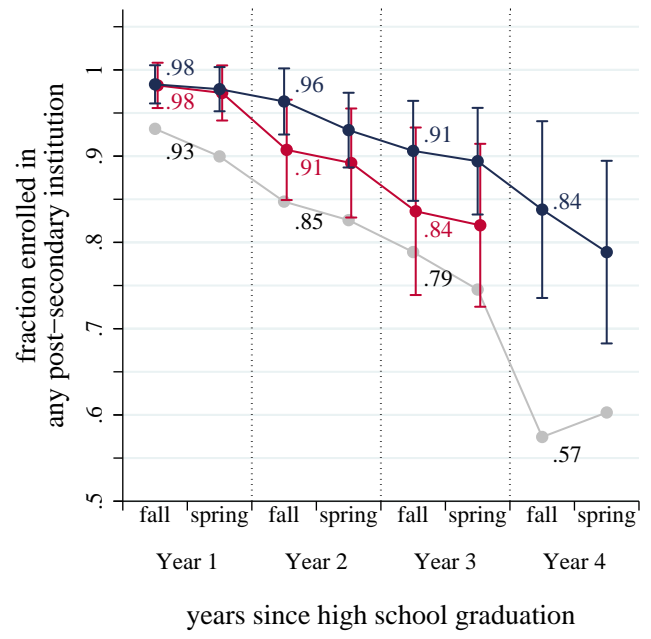

D. Kearney

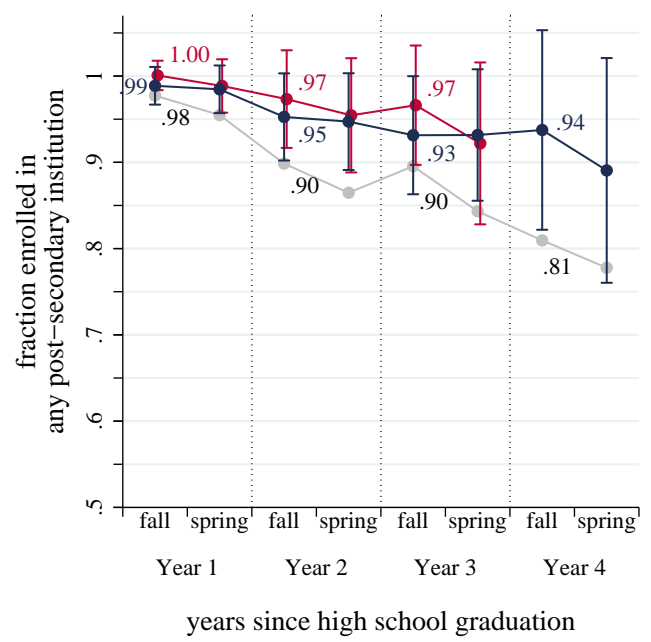

years since high school graduation

\section{$\longrightarrow$ STBF Treated $\longrightarrow$ COS Treated $\longrightarrow$ Control}

Notes: These graphs compare STBF and COS award effects for applicants who targeted University of Nebraska campuses. Panel A pools all NU randomized applicants, and Panels B-D disaggregate results by target campus. Grey lines plot enrollment rates for control applicants, blue lines plot the sum of control means and strata-adjusted treatment effects for traditional STBF scholarship offers, and red lines plot corresponding effects for aid-only COS awards. Whiskers indicate 95 percent confidence intervals. Samples vary across time horizons as defined in Figure 1. COS awards were introduced in the second study cohort, so data on COS award winners are only available through year three. 


\section{Figure 6}

\section{Comparing Financial Aid Effects With and Without Learning Community Services}

by High School GPA

A. GPA $\geq 3.5$

(above sample median)

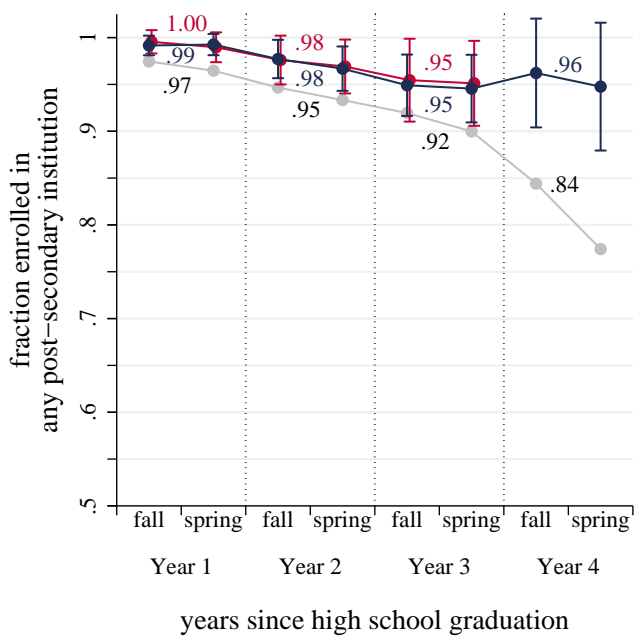

B. GPA $<3.5$

(below sample median)

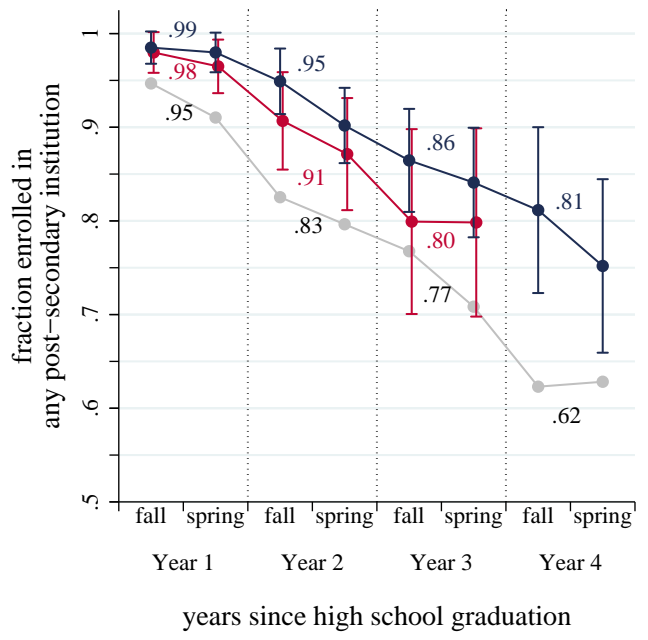

$\longrightarrow$ STBF Treated $\longrightarrow$ COS Treated $\longrightarrow$ Control

Notes: These graphs compare STBF and COS award effects by high school GPA for applicants who targeted University of Nebraska campuses. Grey lines plot enrollment rates for control applicants, blue lines plot the sum of control means and strata-adjusted treatment effects for traditional STBF scholarship offers, and red lines plot corresponding effects for aid-only COS awards. Whiskers indicate 95 percent confidence intervals. Samples vary across time horizons as specified in Figure 1. COS awards were introduced in the second study cohort, so data on COS award winners are only available through year three. 


\section{Figure 7}

Projecting Award Effects on Bachelor's Degree Completion in the Four-Year College Strata

\section{A. Unweighted Estimates}

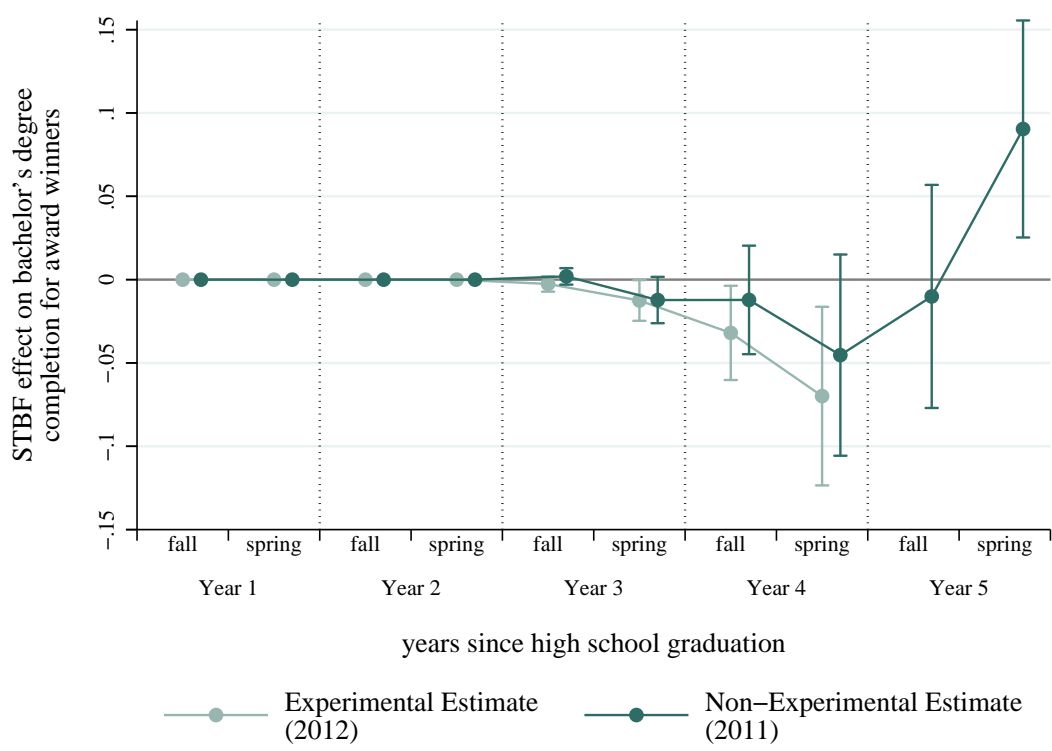

\section{B. Reweighted Projections}

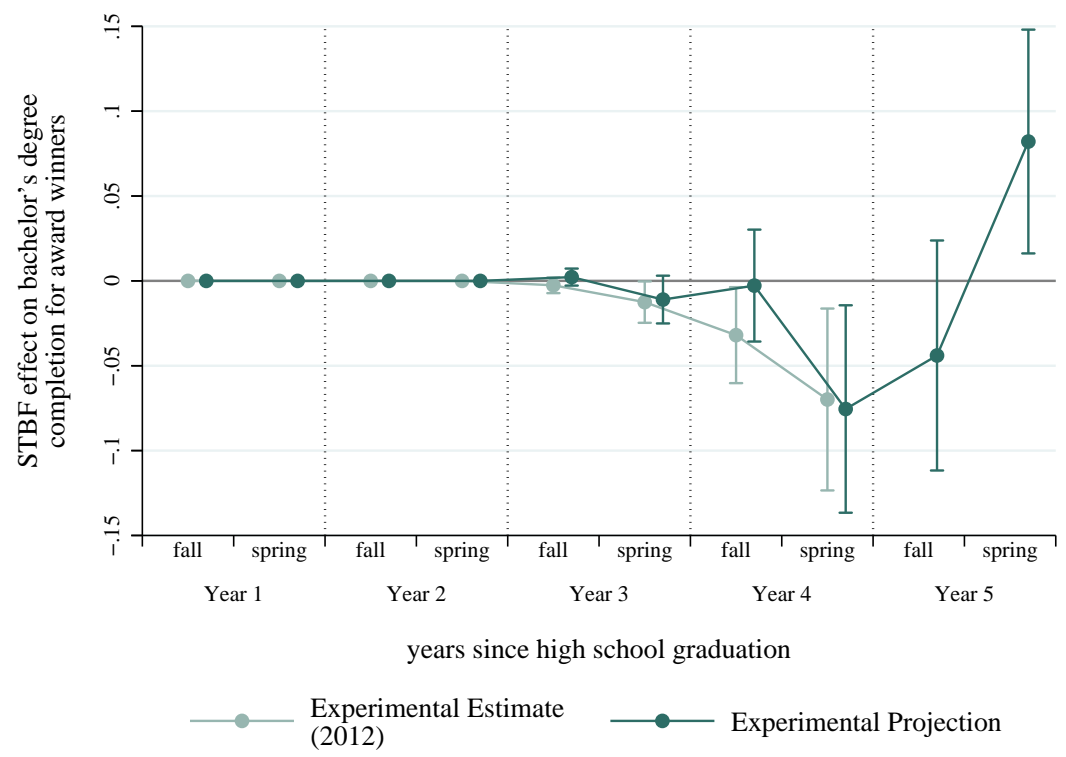

Notes: The light green lines plot estimated effects of award offers on bachelor's degree completion in the four-year college strata for the 2012 experimental cohort. The dark green line in Panel A presents corresponding estimates from the 2011 non-experimental cohort, the last application cohort before the experiment began. The estimates in Panel A control for target college, high school GPA, EFC, gender, race, and parental education using Kline's (2011) Oaxaca-Blinder procedure. In Panel B, we project graduation rates for the experimental sample by reweighting the non-experimental Kline estimates using the distribution of covariates in the experimental sample. Whiskers indicate 95 percent confidence intervals. 
Table 1

Descriptive Statistics

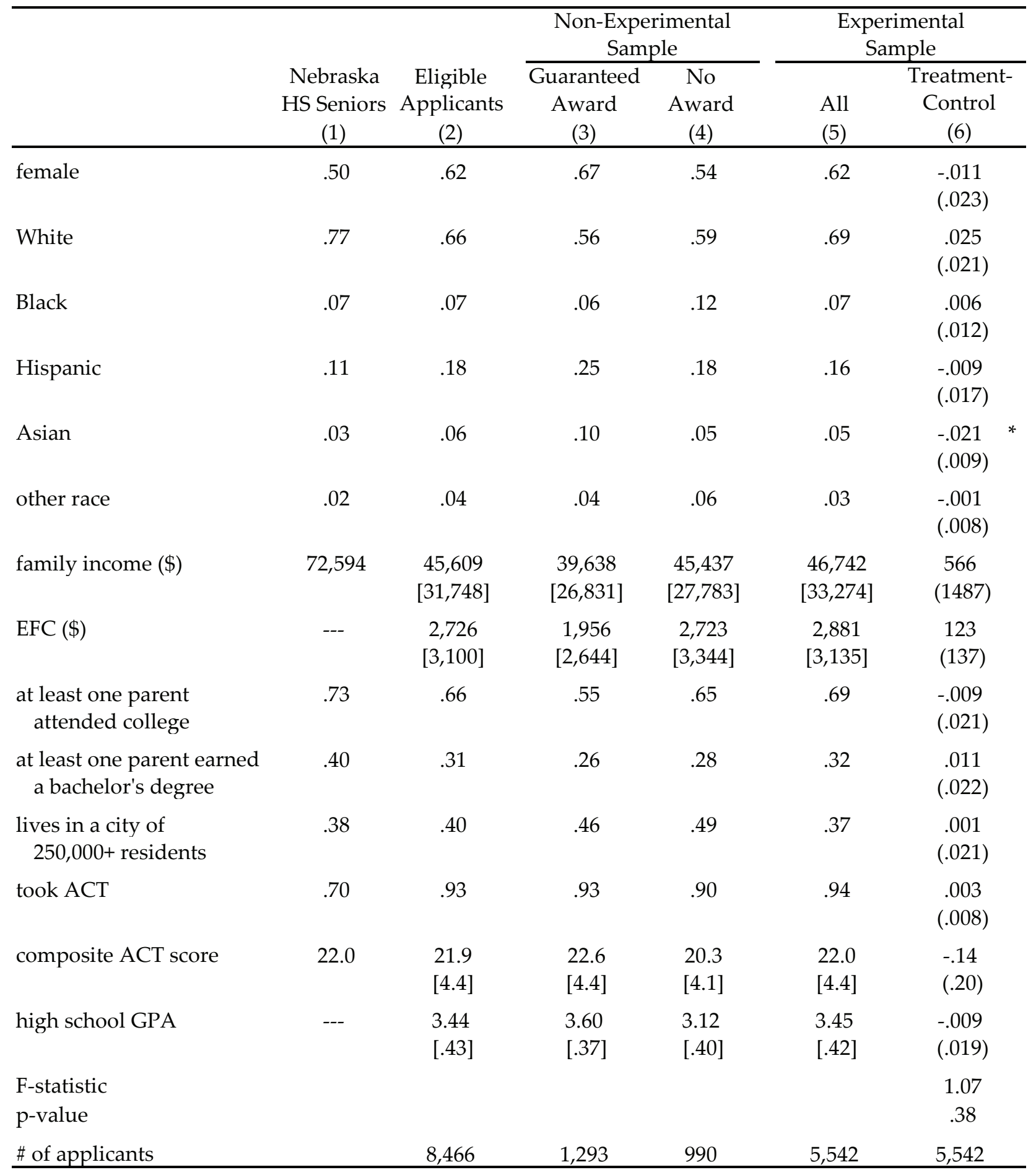

Notes: The treatment-control differences in column 6 come from regressions that control for strata dummies (cohort by target college). Columns 5 and 6 exclude the 641 applicants offered COS awards. The sample includes the 20122015 applicant cohorts. Missing values for race (6\%), family income (5\%), and ACT (7\%) are imputed from means within strata in the sample of eligible applicants. The data appendix provides further detail on data sources and variable definitions for the benchmark descriptive statistics in column 1.

${ }^{* * *} \mathrm{p}<0.01,{ }^{* *} \mathrm{p}<0.05,{ }^{*} \mathrm{p}<0.10$ 
$\underline{\text { Table } 2}$

Effects on Year One Financial Aid Packages

for Nebraska Public College Students

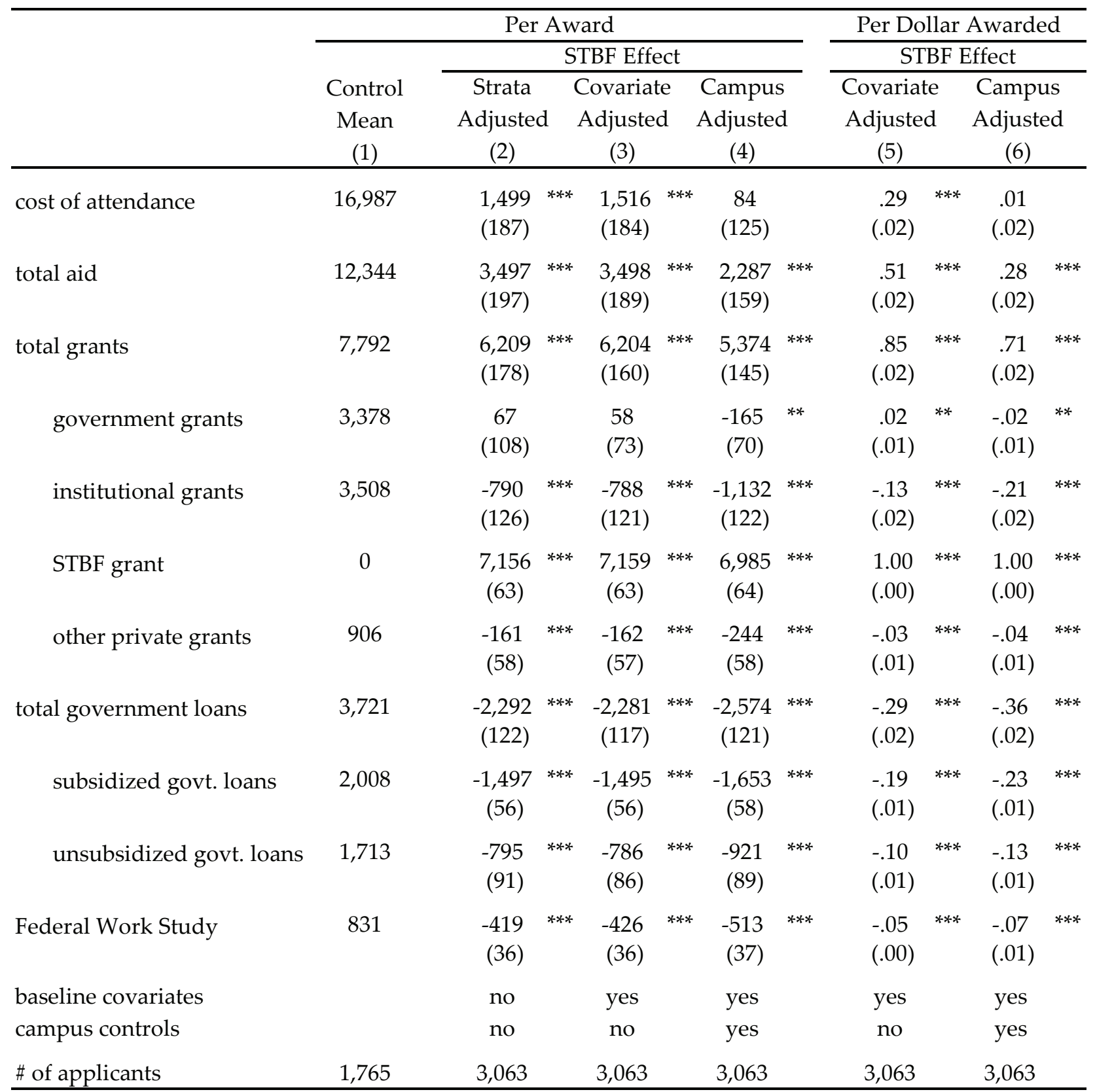

Notes: This table reports effects of STBF scholarship offers on students' financial aid packages. The sample is restricted to students in the 2012-2014 applicant cohorts enrolled in Nebraska public colleges. Aid data are currently unavailable for the 519 students at state colleges and Mid-Plains Community College. Columns 2-4 report results from regressions of the financial aid awarded in each category on a dummy for winning a scholarship, while columns 5 and 6 report results from regressions of the same dependent variables on the dollar value of STBF scholarships awarded. The baseline covariates in columns 3-6 are GPA, EFC, gender, race, and parental education. Columns 4 and 6 also control for cumulative enrollment at each campus. Government grants include federal and state grants.

Subsidized government loans are the sum of Perkins and subsidized Stafford loans; unsubsidized government loans are the sum of PLUS and unsubsidized Stafford loans.

${ }^{* * *} \mathrm{p}<0.01,{ }^{* *} \mathrm{p}<0.05,{ }^{*} \mathrm{p}<0.10$ 
Table 3

Effects on Initial College Choice

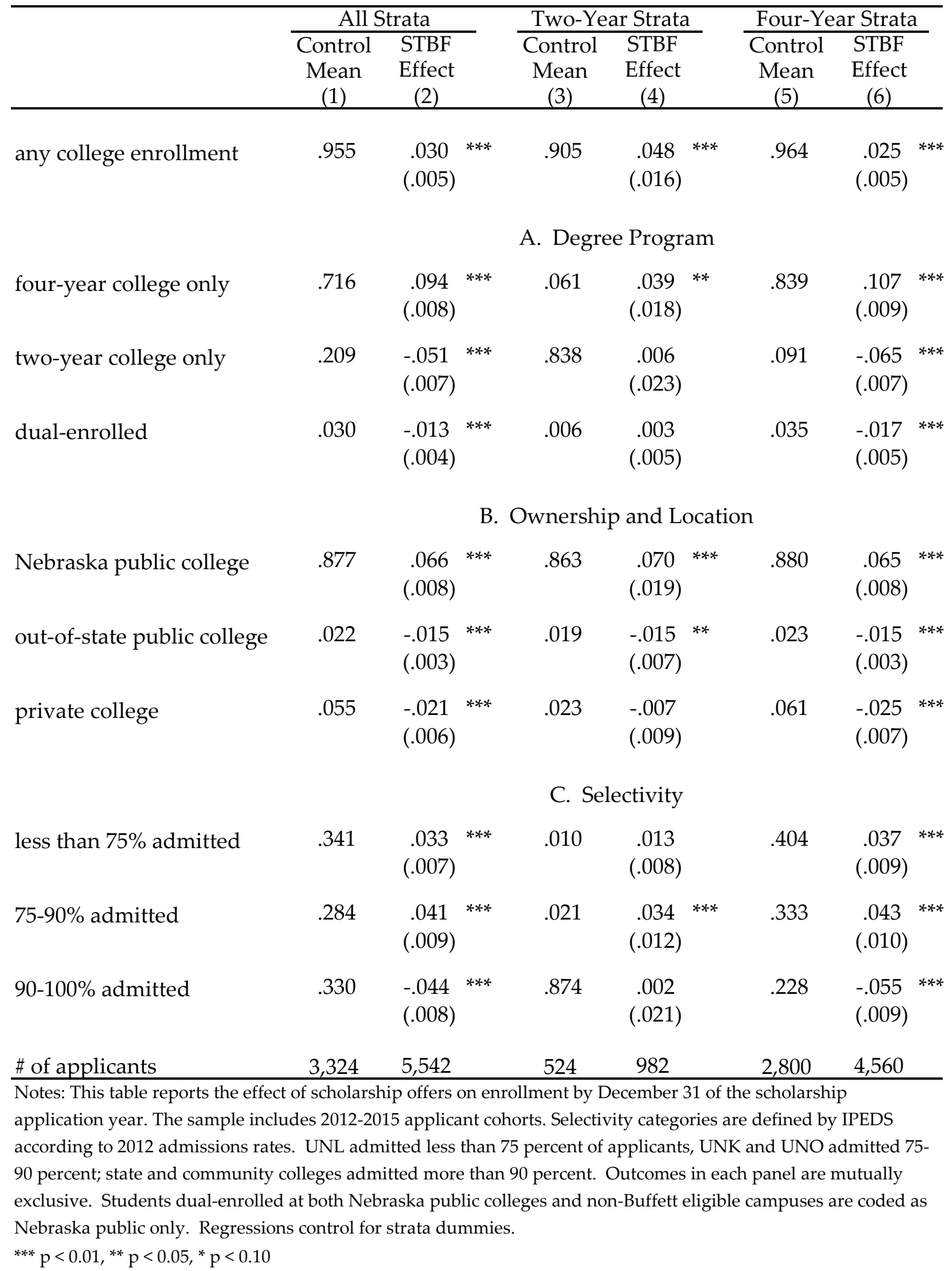




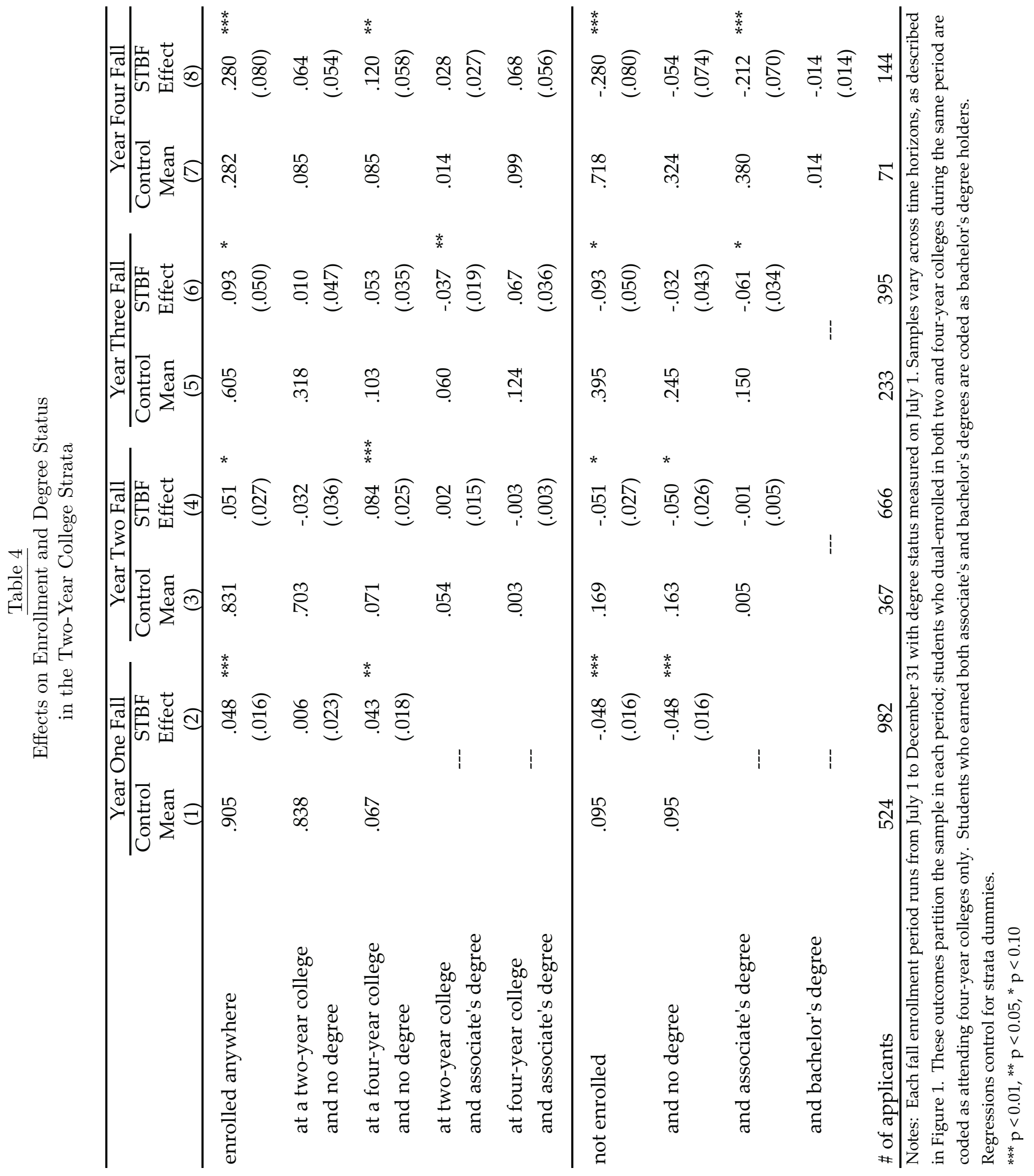




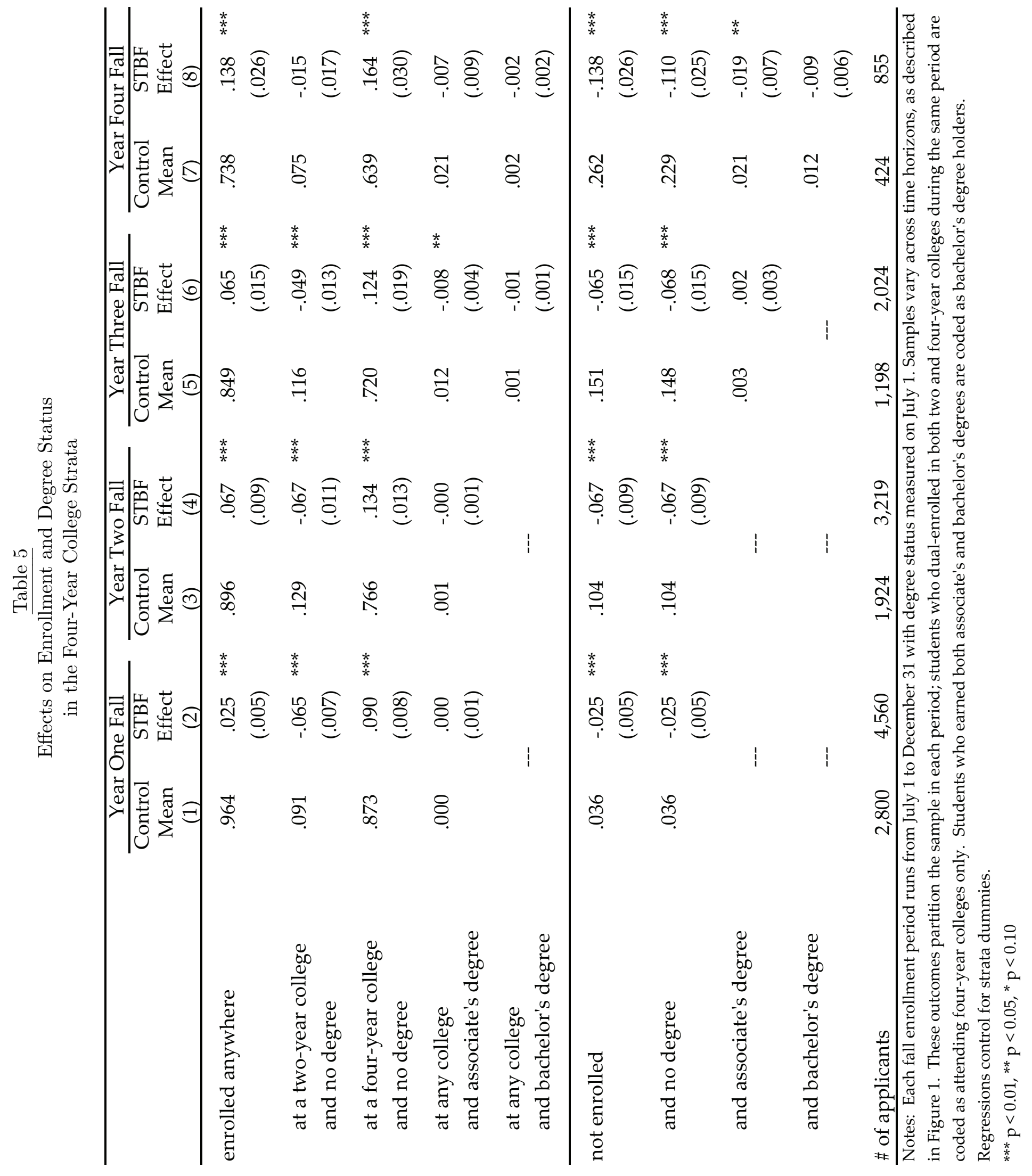


Table 6

Effects on Degree Completion by the End of Year Four

\begin{tabular}{|c|c|c|c|c|c|}
\hline & \multicolumn{2}{|c|}{ Two-Year Strata } & \multicolumn{3}{|c|}{ Four-Year Strata } \\
\hline & $\begin{array}{l}\text { Control } \\
\text { Mean } \\
(1)\end{array}$ & $\begin{array}{l}\text { STBF } \\
\text { Effect } \\
(2)\end{array}$ & $\begin{array}{l}\text { Control } \\
\text { Mean } \\
(3)\end{array}$ & $\begin{array}{c}\text { STBF } \\
\text { Effect } \\
(4) \\
\end{array}$ & \\
\hline bachelor's degree earned & .056 & $\begin{array}{c}.054 \\
(.047)\end{array}$ & .281 & $\begin{array}{l}-.059 \\
(.029)\end{array}$ & ** \\
\hline associate's degree earned & .521 & $\begin{array}{l}-.119 \\
(.079)\end{array}$ & .050 & $\begin{array}{l}-.024 \\
(.013)\end{array}$ & * \\
\hline enrolled at four-year college & .099 & $\begin{array}{c}.040 \\
(.053)\end{array}$ & .019 & $\begin{array}{l}-.005 \\
(.009)\end{array}$ & \\
\hline no degree earned & .423 & $\begin{array}{c}.065 \\
(.078)\end{array}$ & .670 & $\begin{array}{c}.083 \\
(.030)\end{array}$ & $* * *$ \\
\hline enrolled at four-year college & .056 & $\begin{array}{c}.038 \\
(.044)\end{array}$ & .370 & $\begin{array}{c}.188 \\
(.033)\end{array}$ & $* * *$ \\
\hline \# of applicants & 71 & 144 & 424 & 855 & \\
\hline $\begin{array}{l}\text { Notes: This table reports effects on de } \\
\text { cohort. Students who earned both ass } \\
\text { holders. Regressions control for strata }\end{array}$ & $\begin{array}{l}\text { ee completi } \\
\text { ate's and b } \\
\text { mmies. }\end{array}$ & $\begin{array}{l}\text { y the end } \\
\text { lor's deg1 }\end{array}$ & ar four for $t$ & $\begin{array}{l}2012 \text { appl } \\
\text { nelor's de }\end{array}$ & $\begin{array}{l}\text { cant } \\
\text { gree }\end{array}$ \\
\hline${ }^{* * *} \mathrm{p}<0.01, * * \mathrm{p}<0.05,{ }^{*} \mathrm{p}<0.10$ & & & & & \\
\hline
\end{tabular}




\section{Data Appendix}

\section{Application Data}

The STBF scholarship application provides detailed data on applicants' baseline characteristics. The academic measures come primarily from high school transcripts, which report GPA and ACT scores. We standardize GPAs to a 4.0 scale using grade conversion formulae provided by the University of Nebraska-Lincoln. Since not all high schools report ACT scores on their transcripts, we supplement transcript data with self-reported scores from the scholarship application for 50 percent of the experimental sample.

Most of our financial and demographic data come from applicants' Student Aid Reports (SARs). These reports are available for STBF applicants who filed the Free Application for Federal Student Aid (FAFSA). SARs contain responses to more than 100 FAFSA questions regarding students' financial resources and family structure, including family income, parental marital status, and education. Roughly three percent of scholarship applicants are undocumented immigrants, who are ineligible for federal financial aid and therefore cannot file the FAFSA. STBF permits these students to submit an alternate form called the College Funding Estimator (CFE). The CFE is published by the EducationQuest Foundation, a non-profit organization in Nebraska, and gathers similar though less detailed information.

Neither SARs nor CFEs report students' race, and the scholarship application did not collect this variable until 2014. We obtained race data for all cohorts from the Nebraska Department of Motor Vehicles (DMV). After combining the DMV and self-reported data, we observe race for 89 percent of randomized applicants before 2014 and over 99 percent from 2014 onward. We impute race where missing using means within application strata.

\section{Enrollment Data}

More than 90 percent of experimental subjects enrolled in Nebraska public colleges, which provide administrative records for this research. We match applicants to these data using name, gender, date of birth, and the last four digits of Social Security Numbers. To measure enrollment at out-of-state and private institutions, we match applicants to National Student Clearinghouse 
(NSC) data using name and date of birth. Though the NSC captures more than 91 percent of enrollment nationwide (and more than 99 percent at four-year public institutions), its name-based match has limitations, as Dynarski, Hemelt and Hyman (2015) detail. Roughly two percent of experimental applicants have enrollment spells at Nebraska public colleges that do not appear in our NSC-matched sample.

We define post-award years to match the federal financial aid year, which runs from July 1 to June 30, and divide each year into fall and spring halves. Within each fall and spring term, we require binary enrollment outcomes to be mutually exclusive. Students who enroll at both two- and four-year institutions are coded as four-year college students. Likewise, those who enroll at in-state public colleges do not contribute to the out-of-state or private categories, and selectivity outcomes are defined by the most-selective institution attended.

\section{Financial Aid Data}

Nebraska's public colleges also provide detailed information on their students' financial aid packages, which we analyze in Table 2. These data report costs of attendance, grants, loans, and Federal Work Study aid. While all schools report federal loans, most do not report private loans, which may be obtained directly from lenders without involving financial aid officers. We therefore exclude private loans from our analysis. For most students in our sample, federal loans offer the lowest available interest rate and therefore account for the vast majority of borrowing.

\section{Other Descriptive Statistics}

Table 1 compares STBF applicants to the broader population of Nebraska high school seniors. We estimate the race and sex composition of Nebraska seniors using 18-year-old Nebraskans in the 2012 sample of the Surveillance, Epidemiology, and End Results population data (SEER, 2015). Parental education and family income figures come from 12th-grade Nebraska residents in the 2012 wave of the American Community Survey (U.S. Census Bureau 2014). There are two Nebraska cities with more than 250,000 residents: Lincoln and Omaha. We estimate the share of high school seniors who live in Lincoln and Omaha using enrollment figures from the Common Core of Data and Private School Survey (US DOE, 2010a; 2010ㅁ). ACT provides data on Nebraska test takers (ACT 2012). 


\section{Figure A1}

Effects on Year-Two Fall Enrollment by ACT and Family Income in the Four-Year College Strata

A. Any College Enrollment

by ACT

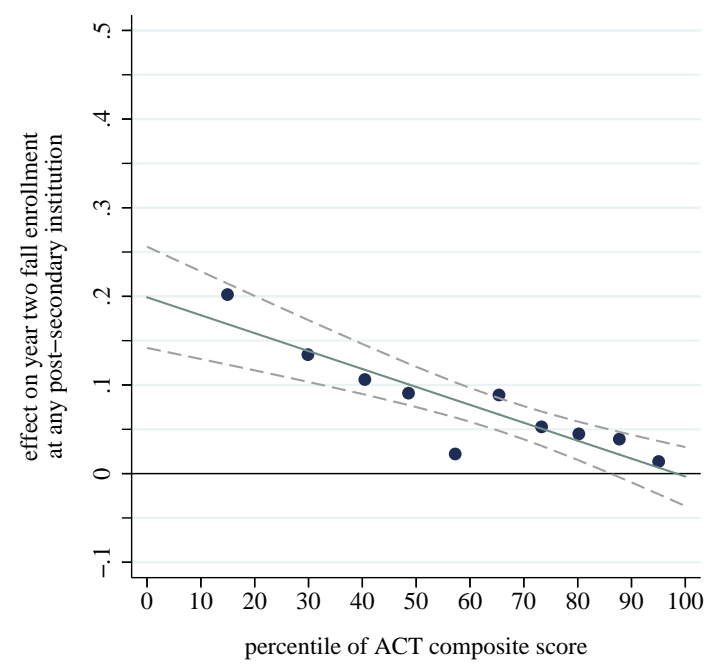

C. Any College Enrollment

by Family Income

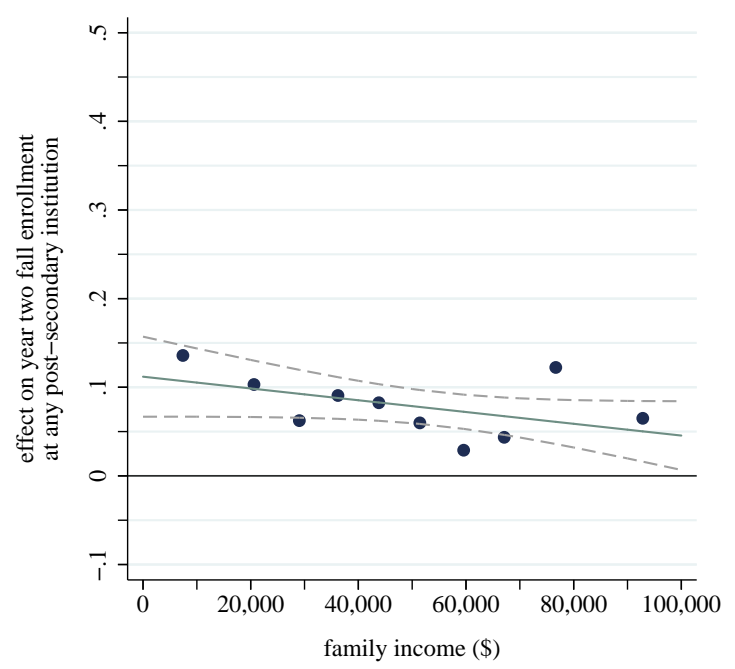

B. Four-Year College Enrollment by ACT

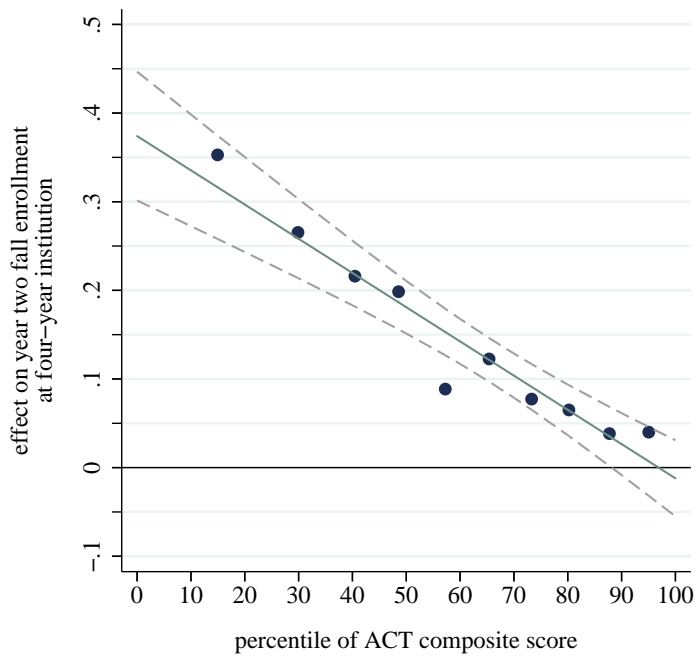

D. Four-Year College Enrollment by Family Income

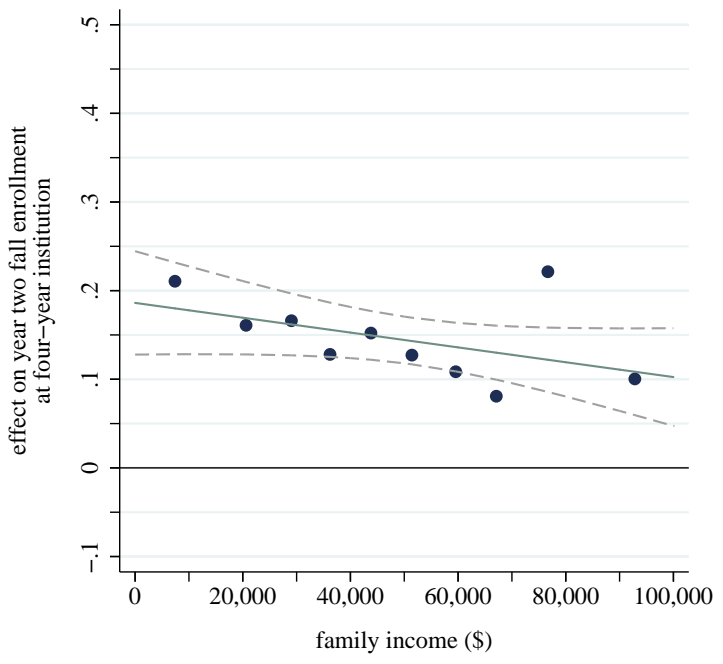

- Bin-Specific Effect — Linear Effect

Notes: These graphs document how award effects vary with ACT composite score and family income. The outcome in each panel is year-two fall enrollment. The sample includes applicant cohorts 2012-2014. Dots plot treatment effects of traditional STBF scholarship offers for deciles of the given trait. Solid lines plot fitted values from regression models that estimate the linear interaction between award status and the given trait. Dotted lines plot 95 percent confidence intervals for the linear fitted values. ACT scores have been converted to percentiles in the distribution of Nebraska ACT test takers. 
Table A1

Baseline Sample Selection

\begin{tabular}{|c|c|c|c|c|c|c|}
\hline \multirow[b]{2}{*}{ Target College } & \multirow[b]{2}{*}{$\begin{array}{c}\text { Eligible } \\
\text { Applicants } \\
(1)\end{array}$} & \multicolumn{2}{|c|}{$\begin{array}{l}\text { Non-Experimental } \\
\text { Sample }\end{array}$} & \multicolumn{3}{|c|}{$\begin{array}{l}\text { Experimental } \\
\text { Sample }\end{array}$} \\
\hline & & $\begin{array}{c}\text { Guaranteed } \\
\text { Award } \\
(2) \\
\end{array}$ & $\begin{array}{c}\text { No } \\
\text { Award } \\
(3) \\
\end{array}$ & $\begin{array}{c}\text { Control } \\
(4)\end{array}$ & $\begin{array}{c}\text { STBF } \\
\text { Award } \\
(5) \\
\end{array}$ & $\begin{array}{c}\text { COS } \\
\text { Award } \\
(6) \\
\end{array}$ \\
\hline 2012 Total & 1,424 & 298 & 127 & 495 & 504 & \\
\hline Two-Year Strata & 210 & 49 & 17 & 71 & 73 & \\
\hline Four-Year Strata & 1,214 & 249 & 110 & 424 & 431 & \\
\hline UNK & 189 & 36 & 26 & 63 & 64 & \\
\hline UNL & 491 & 110 & 33 & 173 & 175 & \\
\hline UNO & 420 & 91 & 46 & 141 & 142 & \\
\hline State Colleges & 114 & 12 & 5 & 47 & 50 & \\
\hline 2013 Total & 2,252 & 351 & 272 & 936 & 484 & 209 \\
\hline Two-Year Strata & 356 & 40 & 65 & 162 & 89 & 0 \\
\hline Four-Year Strata & 1,896 & 311 & 207 & 774 & 395 & 209 \\
\hline UNK & 248 & 33 & 27 & 71 & 66 & 51 \\
\hline UNL & 835 & 139 & 85 & 369 & 153 & 89 \\
\hline UNO & 554 & 106 & 75 & 181 & 123 & 69 \\
\hline State Colleges & 259 & 33 & 20 & 153 & 53 & 0 \\
\hline 2014 Total & 2,350 & 282 & 391 & 860 & 606 & 211 \\
\hline Two-Year Strata & 330 & 20 & 39 & 134 & 137 & 0 \\
\hline Four-Year Strata & 2,020 & 262 & 352 & 726 & 469 & 211 \\
\hline UNK & 260 & 37 & 38 & 73 & 64 & 48 \\
\hline UNL & 958 & 118 & 167 & 413 & 167 & 93 \\
\hline UNO & 564 & 88 & 123 & 143 & 140 & 70 \\
\hline State Colleges & 238 & 19 & 24 & 97 & 98 & 0 \\
\hline 2015 Total & 2,440 & 362 & 200 & 1,033 & 624 & 221 \\
\hline Two-Year Strata & 391 & 39 & 36 & 157 & 159 & 0 \\
\hline Four-Year Strata & 2,049 & 323 & 164 & 876 & 465 & 221 \\
\hline UNK & 274 & 47 & 11 & 103 & 65 & 48 \\
\hline UNL & 903 & 126 & 68 & 450 & 168 & 91 \\
\hline UNO & 612 & 109 & 68 & 223 & 130 & 82 \\
\hline State Colleges & 260 & 41 & 17 & 100 & 102 & 0 \\
\hline
\end{tabular}

Notes: This table reports sample counts by applicant cohort and target college. The experimental sample contains applicants who were subject to random assignment. COS awards were only offered in the 2013-2015 University of Nebraska strata. 
Table A2

Outcomes Sample Construction

\begin{tabular}{|c|c|c|c|c|c|}
\hline \multirow[b]{2}{*}{ Sample } & \multirow[b]{2}{*}{$\begin{array}{c}\text { Control } \\
(1)\end{array}$} & \multirow[b]{2}{*}{$\begin{array}{c}\text { STBF } \\
\text { Award } \\
(2)\end{array}$} & \multirow[b]{2}{*}{$\begin{array}{c}\text { COS } \\
\text { Award } \\
(3)\end{array}$} & \multicolumn{2}{|c|}{ Total } \\
\hline & & & & $\begin{array}{c}\text { STBF } \\
\text { Sample } \\
(4)\end{array}$ & $\begin{array}{c}\text { COS } \\
\text { Sample } \\
(5)\end{array}$ \\
\hline Year One Total & 3,324 & 2,218 & 641 & 5,542 & 4,501 \\
\hline Two-Year Strata & 524 & 458 & 0 & 982 & 0 \\
\hline Four-Year Strata & 2,800 & 1,760 & 641 & 4,560 & 4,501 \\
\hline UNK & 310 & 259 & 147 & 569 & 716 \\
\hline UNL & 1,405 & 663 & 273 & 2,068 & 2,341 \\
\hline UNO & 688 & 535 & 221 & 1,223 & 1,444 \\
\hline State Colleges & 397 & 303 & 0 & 700 & 0 \\
\hline Year Two Total & 2,291 & 1,594 & 420 & 3,885 & 3,141 \\
\hline Two-Year Strata & 367 & 299 & 0 & 666 & 0 \\
\hline Four-Year Strata & 1,924 & 1,295 & 420 & 3,219 & 3,141 \\
\hline UNK & 207 & 194 & 99 & 401 & 500 \\
\hline UNL & 955 & 495 & 182 & 1,450 & 1,632 \\
\hline UNO & 465 & 405 & 139 & 870 & 1,009 \\
\hline State Colleges & 297 & 201 & 0 & 498 & 0 \\
\hline Year Three Total & 1,431 & 988 & 209 & 2,419 & 1,930 \\
\hline Two-Year Strata & 233 & 162 & 0 & 395 & 0 \\
\hline Four-Year Strata & 1,198 & 826 & 209 & 2,024 & 1,930 \\
\hline UNK & 134 & 130 & 51 & 264 & 315 \\
\hline UNL & 542 & 328 & 89 & 870 & 959 \\
\hline UNO & 322 & 265 & 69 & 587 & 656 \\
\hline State Colleges & 200 & 103 & 0 & 303 & 0 \\
\hline Year Four Total & 495 & 504 & & 999 & \\
\hline Two-Year Strata & 71 & 73 & & 144 & \\
\hline Four-Year Strata & 424 & 431 & & 855 & \\
\hline UNK & 63 & 64 & & 127 & \\
\hline UNL & 173 & 175 & & 348 & \\
\hline UNO & 141 & 142 & & 283 & \\
\hline State Colleges & 47 & 50 & & 97 & \\
\hline
\end{tabular}

Notes: This table reports sample counts for each enrollment time horizon. Each sample draws on data from available applicant cohorts: 2012-2015 for year one; 2012-2014 through year two; 2013-2014 through year three; and 2012 only for year four. Column 4 describes the primary analysis sample, which includes control applicants and STBF award winners. Column 5 includes control applicants, STBF recipients, and COS award winners from the University of Nebraska strata. COS awards were not offered in 2012, so year four outcomes in the COS sample are not yet available. 


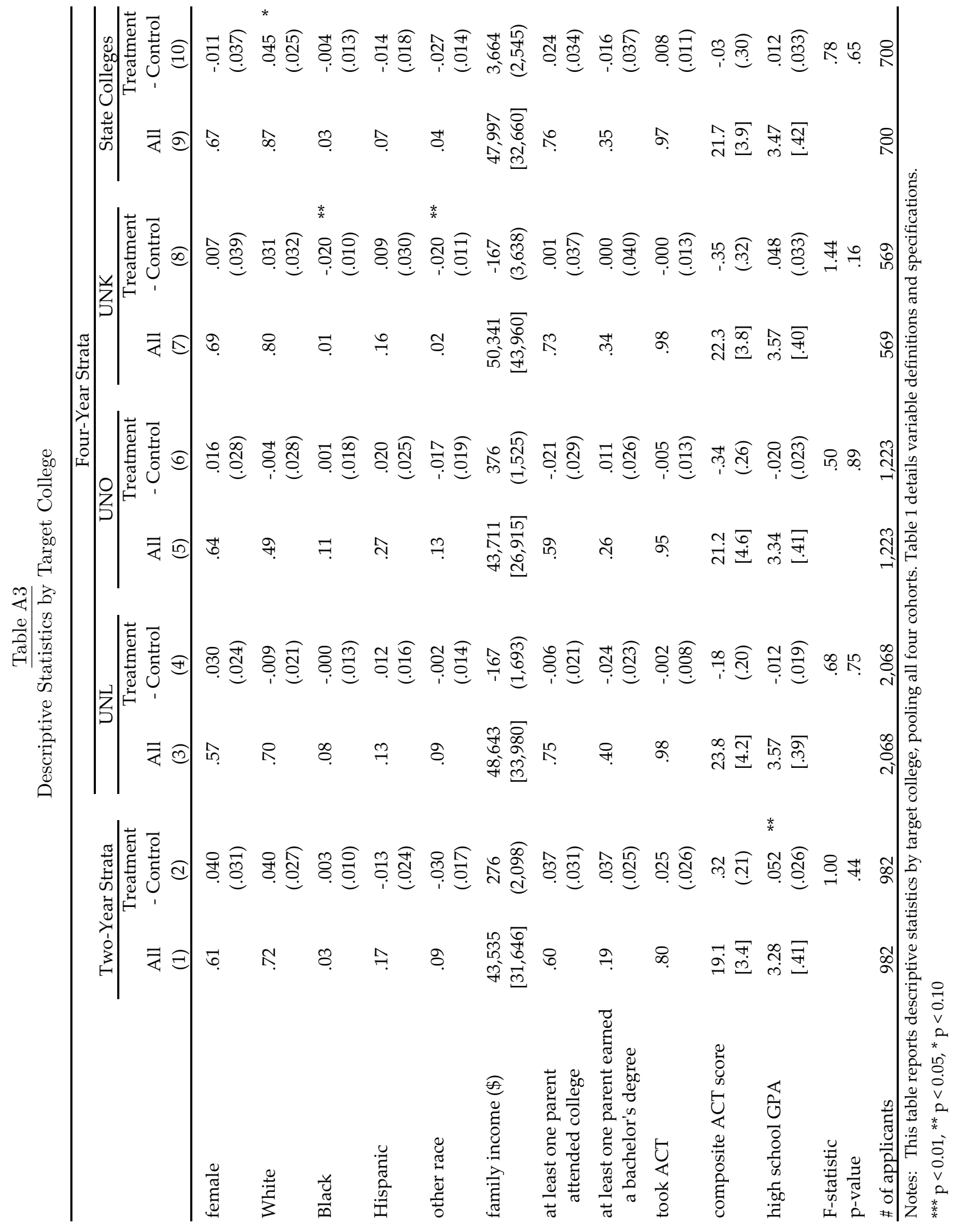




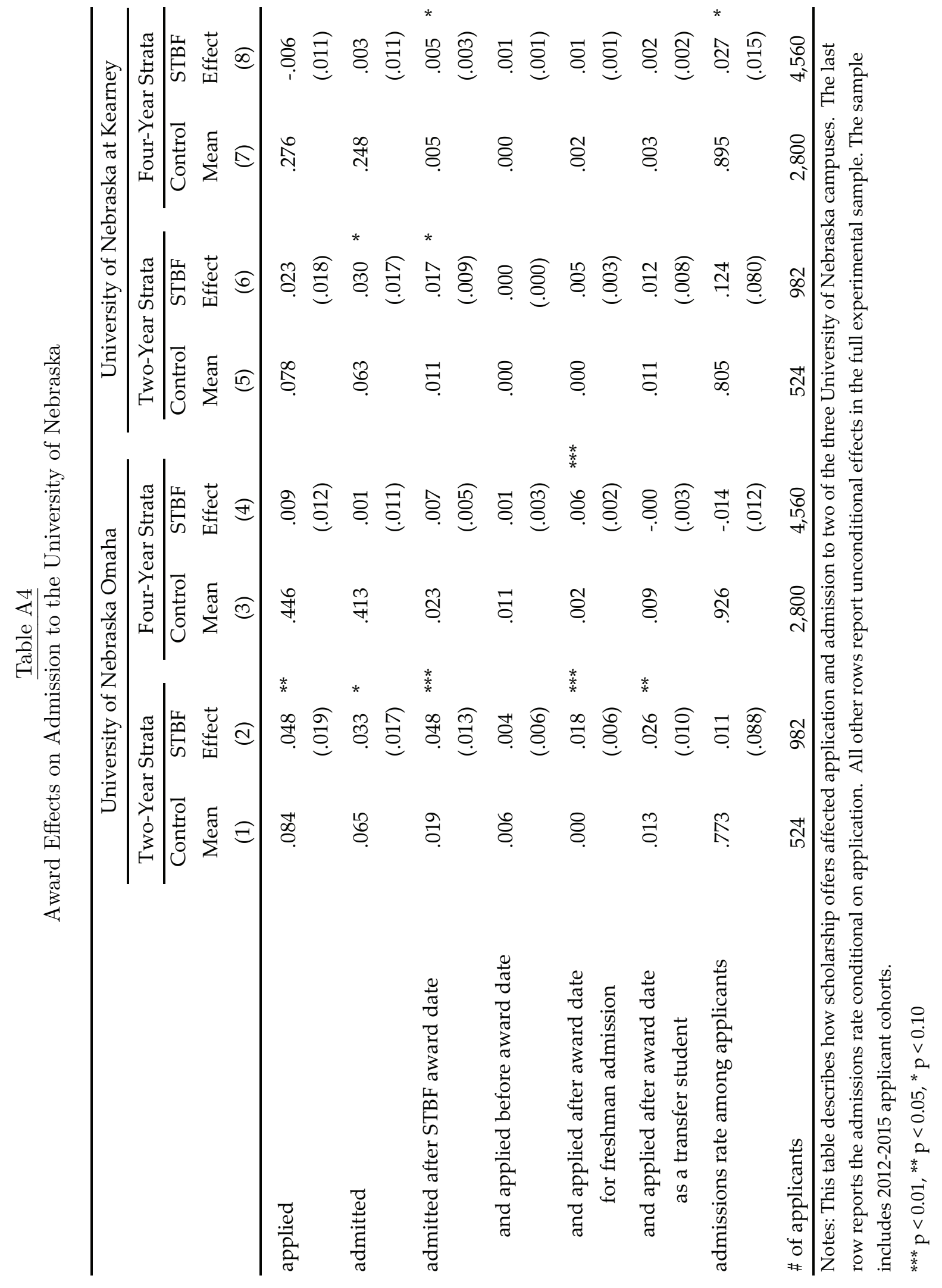




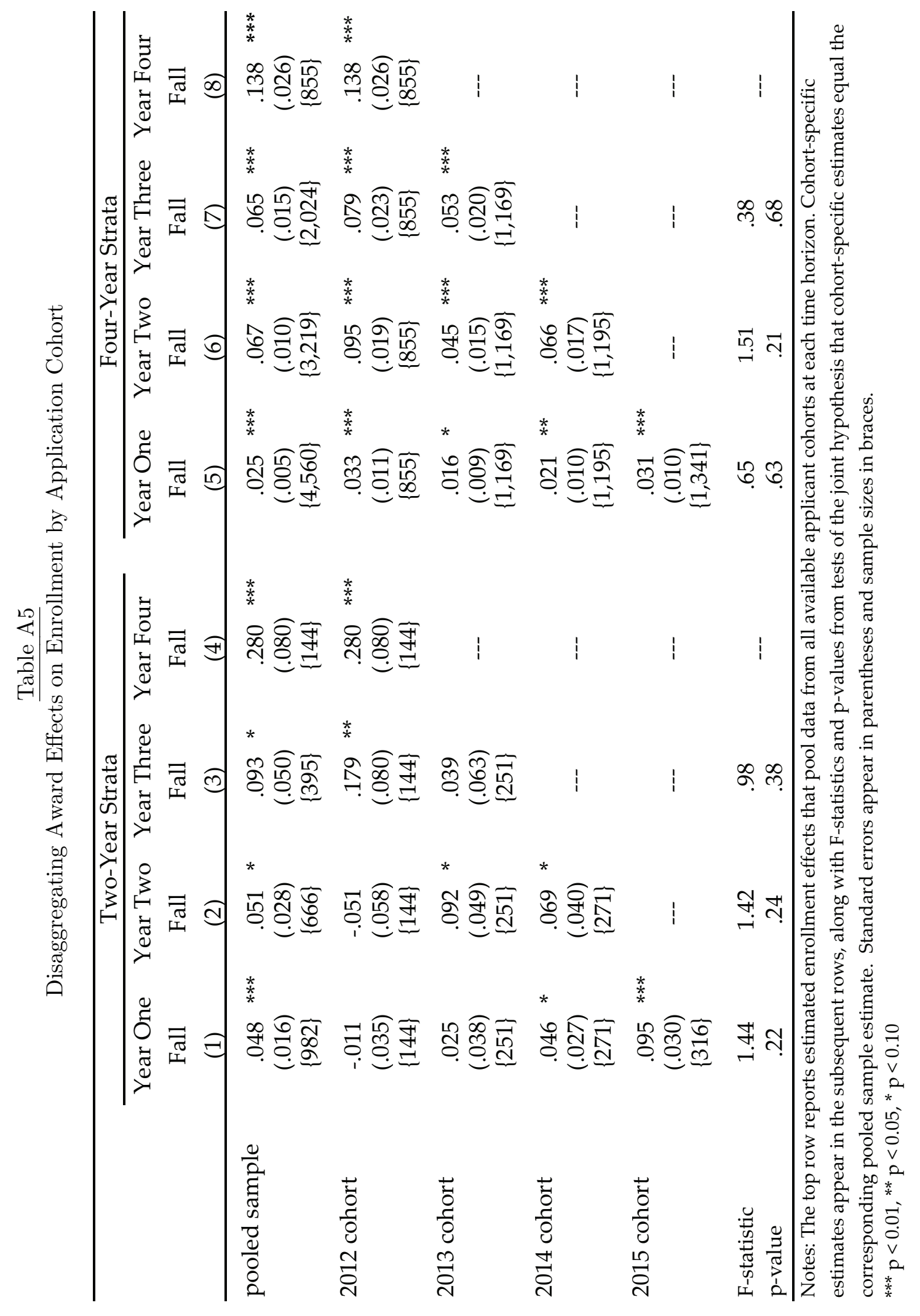




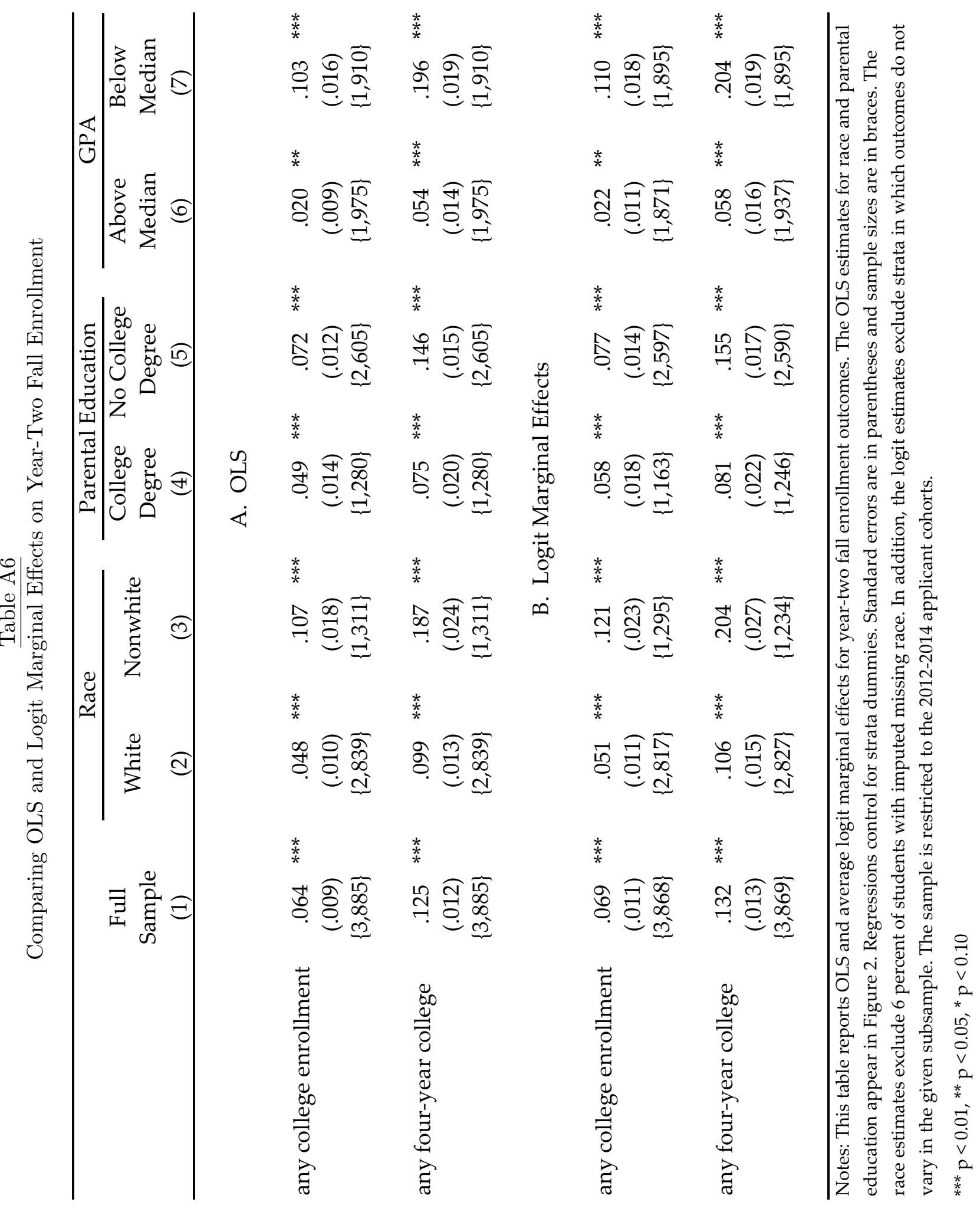


Table A7

Projecting Award Effects on Bachelor's Degree Completion in the Four-Year College Strata

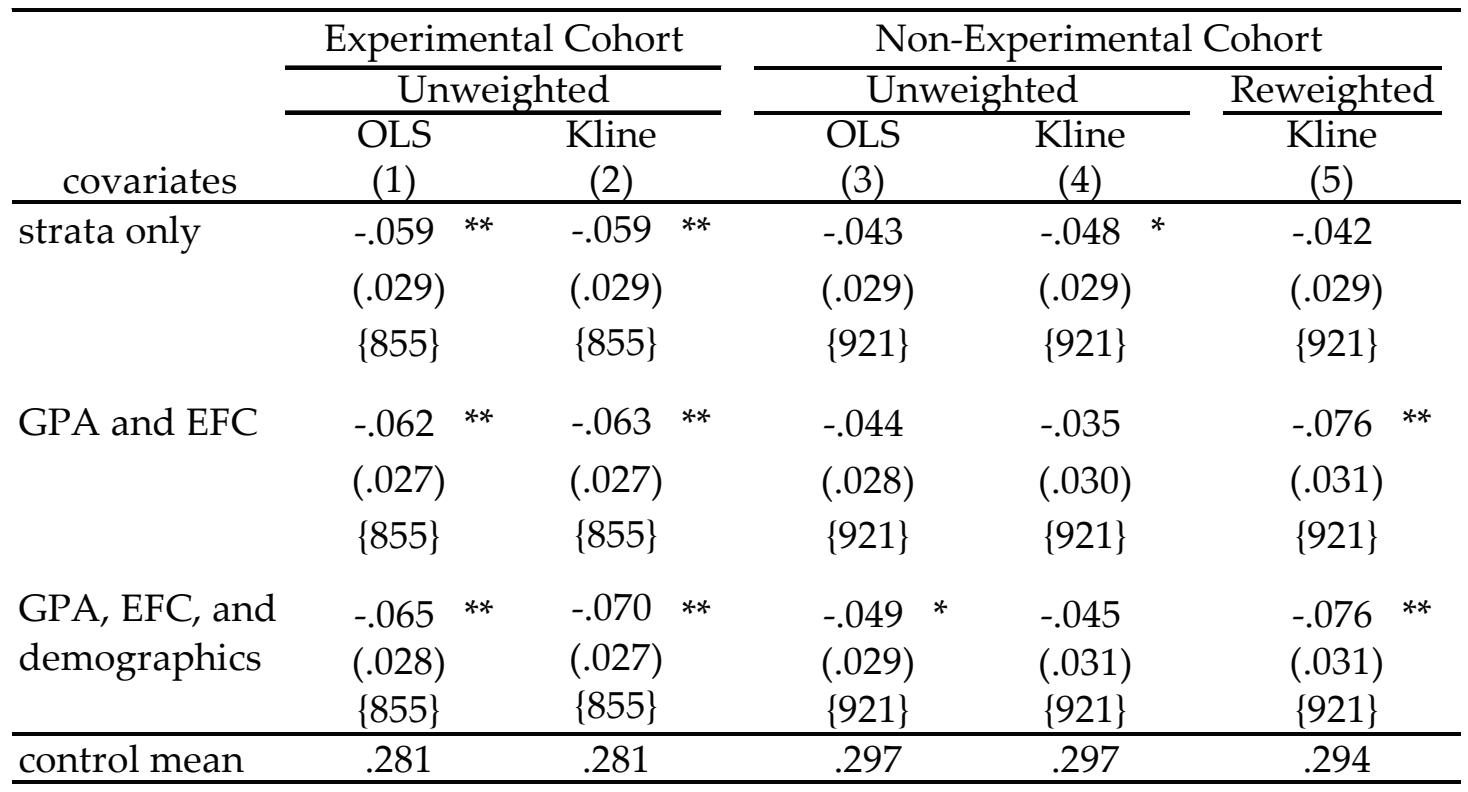

Notes: This table reports estimated effects of STBF award offers on bachelor's degree completion by the end of year four. Columns 1 and 2 present estimates for the 2012 randomized sample using OLS regression and Kline's reweighting procedure. Columns 3 and 4 report corresponding estimates for the 2011 applicant cohort, which was not subject to random assignment. Column 5 reweights the 2011 Kline estimates in column 4 by the distribution of covariates in the 2012 randomized sample. Estimates control for strata dummies. Demographic controls are gender, race, and parental education.

${ }^{* * *} \mathrm{p}<0.01,{ }^{* *} \mathrm{p}<0.05,{ }^{*} \mathrm{p}<0.10$ 